\title{
EFFECT OF MANAGEMENT MODIFICATION ON THE COENOLOGICAL COMPOSITION OF THE NORTH ADRIATIC PASTORAL LANDSCAPE (ĆIĆARIJA, CROATIA)
}

\author{
Ivana VITASOVIĆ KOSIĆ ${ }^{1 *}$, Federico Maria TARDELLA² \& \\ Andrea CATORCI ${ }^{2}$
}

\begin{abstract}
The research aim was to assess the dynamics of the North Adriatic pastoral landscape (Ćićarija, Croatia) with regard to the coenological composition of grassland communities, and, more specifically, to: i) assess the current grassland mosaic from a coenological viewpoint; ii) assess the effects of management abandonment on grassland species composition, also taking into account, as a basis for comparison, data on pastoral communities collected in the past decades. To achieve the research aims, 73 phytosociological relevés were carried out; for each of them field data (altitude, aspect, slope, landform) and information on grassland management were collected. Multivariate analysis of phytosociological relevés led to the identification of four vegetation types (Danthonio-Scorzoneretum villosae, Carici humilis-Centaureetum rupestris, Brachypodium rupestre-dominated stands, and Anthoxantho-Brometum erecti), which were linked to landform and to grassland management. Comparison in terms of social behaviour type composition of the grassland communities surveyed in the present study with the ones surveyed in the past decades, highlighted that the current management (grassland abandonment, as well as low intensity grazing and not periodic mowing) is leading to a percentage loss of pasture and meadow characteristic species, in favour of successional and ruderal ones.
\end{abstract}

Key words: grasslands, North Adriatic, management, phytosociology, social behaviour type.

\section{Izvleček}

Namen raziskave je bil ovrednotiti dinamiko severnojadranske pašniške krajine (Čićarija, Hrvaška) predvsem cenološke sestavo travniških združb. Posebej smo želeli ugotoviti: i) trenuten travniški mozaik s cenološkega vidika, ii) spremembe opuščanja gospodarjenja na vrstno sestavo travnikov s primerjavo podatkov o pašnikih, pridobljenih v preteklih desetletjih. Naredili smo 73 fitocenoloških popisov in za vsakega od njih smo pridobili podatke o višini, legi, nagibu, krajinski obliki in informacijo o gospodarjenju. Z multivariatnimi analizami smo ugotovili štiri vegetacijske tipe (Danthonio-Scorzoneretum villosae, Carici humilis-Centaureetum rupestris, združbo z dominantno vrsto Brachypodium rupestre in Anthoxantho-Brometum erecti), ki smo jih povezali s krajinsko obliko in načinom gospodarjenja. Primerjava sestave zgradbe travniških združb glede na sinsociološko pripadnost vrst med današnjimi in starejšimi popisi je pokazala, da trenuten način gospodarjenja (opuščanje gospodarjenja, nizka intenziteta paše in le občasna košnja) vodi v izgubo značilnih vrst pašnikov in travnikov na račun vrst razvitejših sukcesijskih stadijev in vrst ruderalnih rastišč.

Ključne besede: travniki, severni Jadran, gospodarjenje, fitocenologija, fitosociološka pripadnost vrst.

\footnotetext{
${ }^{1}$ Department of Agricultural Botany, Faculty of Agriculture, University of Zagreb, Svetošimunska 25, 10000 Zagreb, Croatia; e-mail: ivitasovic@agr.hr

${ }^{2}$ School of Environmental Sciences, University of Camerino, via Pontoni 5, I-62032 Camerino (MC), Italy; e-mail: andrea.catorci@unicam.it, dtfederico.tardella@unicam.it

* Corresponding Author
} 


\section{INTRODUCTION}

European semi-natural calcareous grasslands, species-rich ecosystems, have been considered priority habitats by the European Union (92/43/ EEC Directive) and judged worthy of conservation (Pärtel et al. 1999, Norderhaug et al. 2000, Myklestad and Srtersdal 2004, Klimek et al. 2006). Throughout Europe, owing to their low agricultural productivity (Willems 1990, van Dijk 1991), these managed pastures are in strong decline and threatened by abandonment (Luick 1998, Zervas 1998, Dullinger et al. 2003, Sebastià et al. 2008). This trend has been also observed in the North Adriatic pastoral landscape (Kaligaric et al. 2006) and on the Ćićarija mountainous plateau as well (Vitasović Kosić 2011, Vitasović Kosić et al. 2011).

Thus, the understanding of change due to abandonment or management modification is a key factor for biodiversity conservation. Indeed, it is known that grassland management acts as a driving force in plant community diversity (Milchunas \& Lauenroth 1993, Biondini et al. 1998, Collins et al. 1998, MacDonald et al. 2000, Adler et al. 2001, Bullock et al. 2001, Kahmen et al. 2002, Wilson et al. 2003, Frank 2005, Altesor et al. 2006, de Bello et al. 2006, 2007, Catorci et al. 2011). However, the use of simple measurements of species richness to understand plant community shifts due to management modification can lead to misleading conclusions for conservation aims (Campetella et al. 2004). The analysis of plant communities phytosociological composition, instead, has proven useful in understanding ecosystem dynamics and properties (Scheiner 1992, Borhidi 1995, Díaz et al. 2001, Decocq et al. 2004). This approach provides information on the mechanisms underlying species assemblages (Kolasa \& Rollo 1991, Alard \& Poudevigne 2000), allows a better understanding of the relationship between environmental features and plant diversity (Díaz \& Cabido 1997, Lavorel et al. 1997, McIntyre et al. 1999, Pillar 1999, Hunt et al. 2004), and permits modelling floristic and vegetation shifting due to changes in management type or in disturbance intensity (Kelly 1996, Noble \& Gitay 1996, Hobbs 1997, Kleyer 1999). Thus, the assessment of plant communities' coenological composition may provide useful information for the improvement of grassland management practices, according to the principles of adaptive management (Holling 1978).
Our research aim was to assess the dynamics of the North Adriatic pastoral landscape with regard to the coenological composition of grassland communities, using social behaviour types analysis, in consideration of the ongoing process of abandonment of management activities. Hence, the specific research goals were to: i) assess the current grassland mosaic from a coenological viewpoint; ii) assess the effects of management abandonment on grassland species composition, also taking into account, as a basis for comparison, data on pastoral communities collected in the past decades.

\section{MATERIALS AND METHODS}

\subsection{STUdy AREA}

The study area (about 1,000 ha) is located to the north of the Istrian Peninsula, on the Ćićarija mountainous plateau ( $45^{\circ} 29^{\prime} 56^{\prime \prime}-45^{\circ} 30^{\prime} 00^{\prime \prime} \mathrm{N}$, $13^{\circ} 59^{\prime} 54^{\prime \prime}-14^{\circ} 00^{\prime} 29^{\prime \prime} \mathrm{E}$ ), ranging from $250-300$ to $850-900 \mathrm{~m}$ a.s.l., and it is proposed as a Special Protection Area (SPA) of the Natura 2000 network (92/43/EEC Directive) as an important site for habitat $62 \mathrm{~A} 0$ and bird species conservation. The climate is transitional between mediterranean and continental pre-Alpine, with cool, rainy winters and long, dry summers (Poldini 1989). The mean annual temperature is $12.6^{\circ} \mathrm{C}$, the coldest in February $\left(0-2^{\circ} \mathrm{C}\right)$ and the warmest in July or August $\left(18-22^{\circ} \mathrm{C}\right)$. Precipitation is about $1500 \mathrm{~mm}$ /year, most of which falls in autumn; a less pronounced secondary peak occurs as spring turns to summer. From a bioclimatic viewpoint, the study area belongs to the sub-mediterranean belt (Kaligarič 1997) and the epi-mediterranean zone of the mediterranean-mountain vegetation belt (Čarni 2003). The territory is characterised by karstic phenomena (dolines, caves, etc.); the bedrock consists of limestone; soils are generally brown, shallow and clast-rich. Pastures are for the most part undergrazed because of the low density of grazers (sheep) or abandoned; meadows are not regularly mown, are abandoned or, in some cases, derive from seeded forage meadows that have been abandoned (Vitasović Kosić et al. 2011).

The pastoral landscape is characterized by pastures and meadows, referred to the Scorzoneretalia villosae order (Festuco-Brometea class) and Arrhenatheretalia elatioris order (Molinio-Arrhenatheretea class), respectively. 


\subsection{DAta Collection}

Data collection was planned according to a stratified sampling method in order to sample all the topographic conditions, related to altitude, aspect, slope and landform, and all types of grassland use (mowing, grazing, mowing abandonment, and grazing abandonment).

During 2009, 73 relevés were carried out using the Braun-Blanquet method (1964) in $10 \times 10 \mathrm{~m}$ plots $\left(100 \mathrm{~m}^{2}\right)$. Field data (altitude, aspect, slope, landform) and information on grassland management were collected for each plot.

Phytosociological papers which report data collected during the past decades on grasslands of the study area and neighbouring territories (Poldini 1980, 1985, 1989, Poldini \& Oriolo 1994, Kaligarič \& Poldini 1997) were consulted.

Species were grouped in social behaviour types (SBTs) (Borhidi 1995, Bartha et al. 2008, Catorci et al. 2011a). SBTs aggregate species with similar preferences for the associated habitats, i.e. based on their coenological role, that is the role that a plant species plays in the community (Borhidi 1995) considering species in regard to their autoecology, morphology and physiological performances (Alard \& Poudevigne 2000). Species SBTs were assessed in accordance with Mucina et al. (1993), Biondi et al. (2001, 2005), Aeschimann et al. (2004), and Čarni et al. (2005), following the most accepted phytosociological placement of each species: pasture species (characteristic of Festuco-Brometea, Tuberarietea guttatae, and Sedo-Scleranthetea classes); meadow species (characteristic of Molinio-Arrhenatheretea class); successional and ruderal species (characteristic of Trifolio-Geranietea, Rhamno-Prunetea, Querco-Fagetea, Artemisietea vulgaris, and Stellarietea mediae classes).

\subsection{DATA ELABORATION}

Phytosociological relevés were submitted to cluster analysis using the Complete link algorithm (Orloci 1978), based on chord distance. To this purpose Braun-Blanquet values were transformed according to the van der Maarel scale (1979). For the syntaxonomical placement of the grassland types, local phytosociological studies (Poldini 1980, 1985, 1989, Poldini \& Oriolo 1994, Kaligarič \& Poldini 1997) were consulted. The species nomenclature followed the Flora Croatica Database (Nikolić 2011) and Flora d'Italia (Pignatti 1982).
A synoptic table was made to compare the current coenological composition of syntaxa emerging from the phytosociological interpretation of Cićarija grassland communities, with one of the same syntaxa identified in the North Adriatic pastoral landscape by other authors during the past decades (Poldini 1989, Kaligarič \& Poldini 1997). The SBT frequency distribution of each relevé group reported in the synoptic table was calculated.

Cluster analysis was performed using SYNTAX 2000 software (Podani 2001).

\section{RESULTS}

\subsection{Phytosociological analysis}

The multivariate analysis of phytosociological relevés (Figure 1) shows a separation into two main clusters (I and II), the latter divided into two subclusters (IIa, IIb).

Cluster I aggregates relevés ranging from 200-250 to 650-700 (888) $\mathrm{m}$ a.s.l., spread on flat or slightly concave surfaces, on the transition belt between slopes and flat lands, with quite deep soils (Table 1). The assessment of floristic and ecological features allows this community to be referred to the Danthonio-Scorzoneretum villosae association (Scorzonerion villosae alliance). Such grasslands are mainly managed as hay meadows.

Cluster IIa includes relevés ranging from 500-550 to 700-750 (852) m a.s.l., spread on flat or slightly convex relief tops and on slightly or moderately steep slopes, with shallow soils and outcropping rock (Table 2). The assessment of floristic and ecological features enables such a community to be referred to the Carici humilisCentaureetum rupestris association (Saturejion subspicatae alliance). Group IIa is further separated, at a lower dissimilarity level, into two subgroups $\left(\mathrm{IIa}^{1}, \mathrm{IIa}^{2}\right)$, the former referred to grazed pastures, the latter to ungrazed and unmown grasslands, which are referred to a variant differentiated by Brachypodium rupestre.

Cluster IIb aggregates relevés spread generally on flat lands, on the bottom of depressions between relief tops, with deep clayey soils, between 500-550 and 700-750 m a.s.l. (Table 3). From a phytosociological viewpoint they are referred to Anthoxantho-Brometum erecti (Arrhenatherion elatioris alliance). This type of grassland, once used as pasture and hay meadow, at present is mostly unmanaged. 


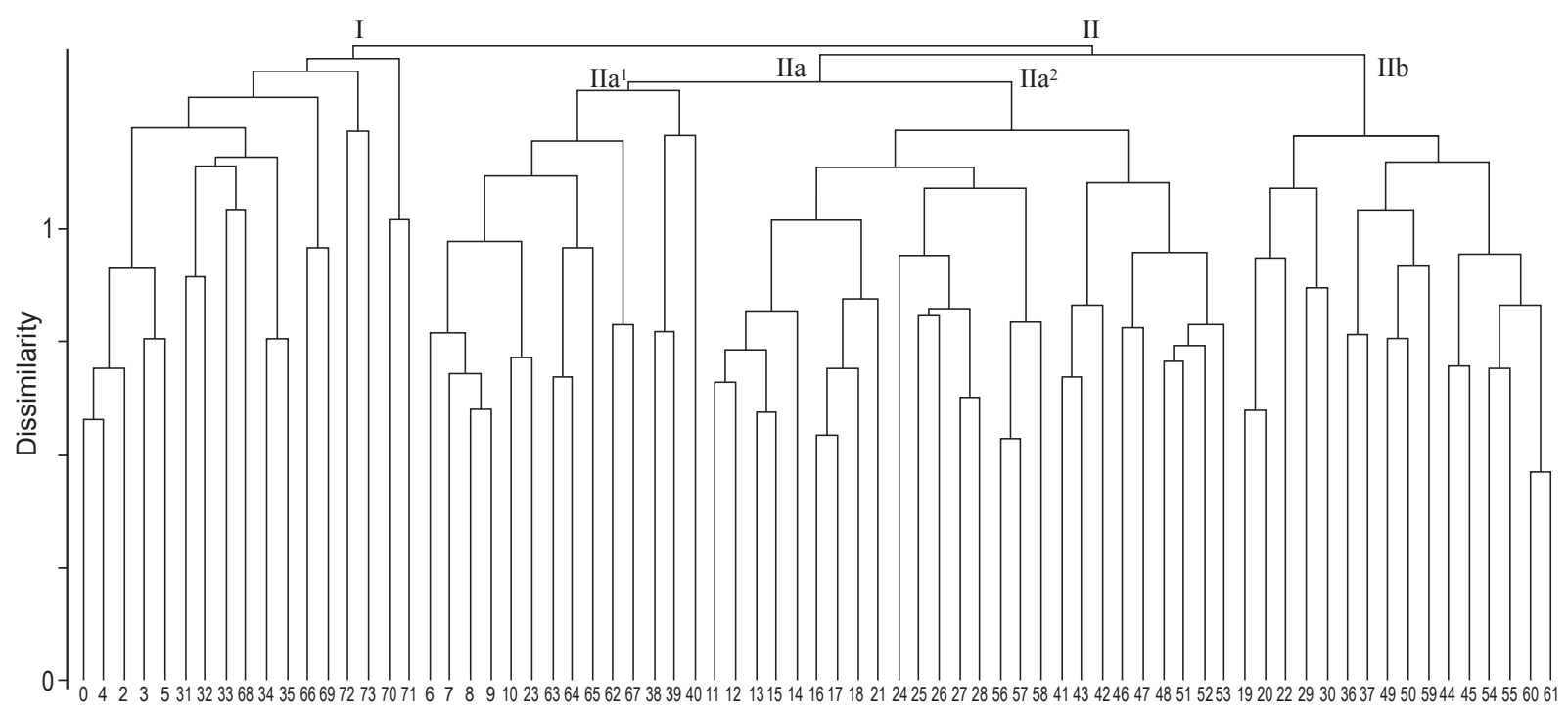

Figure 1: Dendrogram of phytosociological relevés (I - Danthonio-Scorzoneretum villosae; IIa $^{1}$ - Carici humilis-Centaureetum rupestris; $\mathrm{IIa}^{2}$ - Carici humilis-Centaureetum rupestris Brachypodium rupestre variant; IIb - Anthoxantho-Brometum erecti Poldini 1980).

Slika 1: Dendrogram fitocenoloških popisov (I - Danthonio-Scorzoneretum villosae; IIa ${ }^{1}$ - Carici humilis-Centaureetum rupestris; $\mathrm{IIa}^{2}$ - Carici humilis-Centaureetum rupestris Brachypodium rupestre varianta; IIb - Anthoxantho-Brometum erecti Poldini 1980).

The synoptic table (Table 4) shows the comparison of phytosociological composition between the above mentioned groups and the respective syntaxa drawn from the literature (Poldini 1989, Kaligarič \& Poldini 1997).

\subsection{SOCIAL BEHAVIOUR TYPES COMPOSITION}

Table 5 shows the percentage frequency distribution of social behaviour types in each group of relevés reported in the synoptic table (Table 4). With regard to Danthonio-Scorzoneretum villosae, relevés from Ćićarija grasslands, compared with Kaligarič \& Poldini's (1997) ones (Table 5, columns 1 and 2), show a lower frequency of pasture species and a higher occurrence of successional and ruderal elements (mostly from fringe habitats and fallow fields, mainly belonging to Trifolio-Geranietea and Artemisietea vulgaris classes). Similar differences have been observed also in Carici humilis-Centaureetum rupestris (Table 5, columns 3, 4, and 5). Social behaviour types variations are particularly pronounced in abandoned grasslands (cluster $\mathrm{IIa}^{2}$ ), because of the higher percentage of successional and ruderal species, mostly due to herbaceous and woody fringe species (Trifolio-Geranietea and Rhamno-
Prunetea classes), and to nitrophilous elements (Artemisietea vulgaris class). With regard to Anthoxantho-Brometum erecti (Table 5, columns 6 and 7), Ćićarija grasslands have a higher percentage value of successional and ruderal species (in particular belonging to Trifolio-Geranietea, Artemisietea vulgaris, and Rhamno-Prunetea classes), and a lower value of meadow elements, compared with Poldini's (1989) relevés, while the frequency of pasture species is constant.

\section{DISCUSSION}

From the comparison of the relevé groups emerging from multivariate analysis (Figure 1) and of the collected field data (Tables 1-3), it can be observed that relevés segregation into clusters at the highest dissimilarity level is linked to landform, which, in turn, affects soil characteristics. These findings are consistent with plant communities distribution modeling, proposed by Vitanzi et al. (2009), and with Poldini's (1989) description of grassland communities' distribution in relation to landforms. Clusters segregation into subclusters at a lower dissimilarity level mostly depends on grassland use/non-use.

Comparing species composition of the above mentioned syntaxa of grassland communities, 
sampled in the study area, with the ones reported in previous studies (Table 4), it can be argued that, at present, all the plant communities have a relatively high percentage of successional species (mostly herbaceous and shrubby fringe) (Table 5). This is due to grassland abandonment, as observed also by Catorci et al. (2011b) in the Apennines, and, probably, to the low intensity use of the whole pastoral system. More particularly, cluster I (Figure 1) groups relevés in which, apart from the elements of Scorzonerion villosae alliance and of the upper syntaxonomic units, a considerable number of meadow, successional and ruderal elements (transgressive species from Molinio-Arrhenatheretea, Trifolio-Geranietea, and Artemisietea vulgaris classes) occur. In cluster IIa, successional and ruderal species (belonging to Trifolio-Geranietea, Rhamno-Prunetea, and Artemisietea vulgaris classes) are associated with the typical species composition of Saturejion subspicatae alliance and of the upper units. Such elements are more frequent in abandoned pastures (subcluster $\mathrm{IIa}^{2}$ ) than in the ones subjected to a low disturbance intensity (subcluster IIa $^{1}$ ). Cluster IIb aggregates relevés characterized by the typical elements of meadows (Molinio-Arrhenatheretea class) and by a conspicuous number of pasture species (FestucoBrometea class) and of successional and ruderal species (Trifolio-Geranietea, Rhamno-Prunetea, and Artemisietea vulgaris classes). Despite their floristic similarity, mainly due to the dominance of the Molinio-Arrhenatheretea species set, these relevés have a heterogeneous composition, probably because of the different origin of these grasslands. As a matter of fact, they derive from recolonisation processes of abandoned seeded meadows by Molinio-Arrhenatheretea species or, conversely, they are the result of the abandonment of $A r$ rhenatherum elatius-dominated meadows. The lower frequency of meadow species in this group than in Poldini's (1989) relevés, in favour of successional and ruderal ones, can be explained by considering that, in accordance with Catorci \& Gatti (2010), the occurrence of the MolinioArrhenatheretea class characteristic species set is linked to the contemporary presence of mowing, high soil nitrogen content, and high soil Available Water Capacity, so that the abandonment of mowing and/or fertilization cause the loss of Molinio-Arrhenatheretea species.

Moreover, the occurrence of Brachypodium rupestre in Ćićarija unmanaged grassland communities (Tables 2 and 3 ) is consistent with several studies, which emphasize the role of $B$. pinnatum and $B$. rupestre in the invasion of unmanaged grasslands, through processes of competition, and the related conservation problems (During \& Willems 1984, Bobbink \& Willems 1987). The reduction in grazing pressure, for instance, was primarily referred as a cause of the spread of $B$. pinnatum in the United Kingdom (Wilson et al. 1995, Buckland et al. 2001) and of B. rupestre in the Apennines (Bonanomi \& Allegrezza 2004).

Table 6 shows schematically the types of land use (pasture, meadow), their relation with landforms, and the observed dynamic trends of Ćićarija grassland syntaxa, and reports some hypotheses about their evolution in case of protracted abandonment.

\section{CONCLUSIONS}

The coenological analysis of Ćićarija grasslands indicated that grassland abandonment, undergrazing and not periodic mowing (low disturbance) are leading to a coenological variation, which consists in a percentage loss of pasture and meadow characteristic species in ungrazed and unmown grasslands, respectively, in favour of successional and ruderal ones (Vitasović Kosić et al. 2011). More specifically, the analysis of SBT frequencies shifts highlighted that the current management is causing the homogenization of grassland communities coenological composition (Table 5). On the other hand, other studies indicate that intensive farming activities also cause landscape homogenization in central Europe (Poschlod \& Wallis DeVries 2002, Robinson \& Sutherland 2002, Benton et al. 2003, Tscharntke et al. 2005). Thus actually, both high and low intensity use are liable to lead to a progressive homogenization of pastoral landscape.

However, as stated by Bakker (1998), differences in local grazing intensity may be very influential on plant communities' composition, at intermediate scales, while at small scales may cause the occurrence of micro-patterns, resulting in a system of pulsing patches. Moreover, it is known that dry grasslands on steep slopes or shallow soils are more resistant to vegetation change caused by abandonment than grasslands on flatter sites, hence they are more suitable to preserving plant biodiversity; on the contrary, mesophilous meadows are less resistant (Bennie et al. 2006), and hence they are more vulnerable 
than pastures to the loss of species diversity because of management abandonment.

Such considerations suggest that pastures and meadows should be subjected to different types of regulation in order to preserve their diversity. In particular, a general low pressure of grazing can be maintained by means of grazing rotation, favouring the contemporary presence of ungrazed, undergrazed and moderately grazed pasture patches, while intensive grazing should be avoided because of the low resilience of dry pastures (Hirst et al. 2005). In pastures abandoned a long time ago, shrub clearing should be planned. In meadows, regular mowing should be maintained and incentivized; moreover, fertilization might be necessary, in specific cases, to improve productivity and preserve the meadow characteristic species set. Finally, the implementation of management plans for Ćićarija grasslands will contribute to protecting one of the biodiversity hot spots in Europe, proposed as a Special Protection Area (SPA) of the Natura 2000 network, rich in endemisms, threatened plant species and floristic entities that reach in this area the edge of their range.

\section{ACKNOWLEDGEMENTS}

We wish to thank Dr. Mirko Ruščić for his help during field work and unknown reviewers for improving the manuscript.

\section{REFERENCES}

Adler, P., Raff, R. \& Lauenroth, W. K. 2001: The effect of grazing on the spatial heterogeneity of vegetation. Oecologia 128: 465-479.

Aeschimann, D., Lauber, K., Moser, D. M. \& Theurillat, J. P. 2004: Flora alpina. 1-3. Zanichelli, Bologna, 2670 pp.

Alard, D. \& Poudevigne, I. 2000: Diversity patterns in grasslands along a landscape gradient in northwestern France. Journal of Vegetation Science 11: 287-294.

Altesor, A., Piñero, G., Lezama, F., Jackson, R. B., Sarasola, M. \& Paruelo, J. M. 2006: Ecosystem changes associated with grazing in subhumid South American grassland. Journal of Vegetation Science 17: 323-332.

Bartha, S., Merolli, A., Campetella, G. \& Canullo, R. 2008: Changes of vascular plant diversity along a chronosequence of beech coppice stands, central Apennines, Italy. Plant Biosystems 142: 572-583.

Bakker, J. P. 1998: The impact of grazing on plant communities. In: Wallis De Vries, M. F., Bakker, J. P., van Wieren, S. E. (eds.): Grazing and Conservation Management. Conservation Biology Series. Kluver Academic Publishers, pp. 137-184.

Bennie, J., Hill, M. O., Barter, R. \& Huntley, B. 2006: Influence of slope and aspect on longterm vegetation change in British chalk grasslands. Journal of Ecology 94: 355-368.

Benton, T. G., Vickery, J. A. \& Wilson, J. D. 2003: Farmland biodiversity: is habitat heterogeneity the key? Trends in Ecology and Evolution 18: 182-188.

Biondi, E., Allegrezza, M. \& Zuccarello, V. 2005: Syntaxonomic revision of the Apennine grassland belonging to Brometalia erecti and an analysis of their relationship with the xerophilous vegetation of Rosmarinetea officinalis. Phytocoenologia 35(1): 129-163.

Biondi, E., Čarni, A., Vagge, I., Taffetani, F. \& Ballelli, S. 2001: The vegetation of the Trifolio medii-Geranietea sanguinei Müller 1962 class in the central part of the Apennines (Italy and San Marino). Fitosociologia 38(1): 55-65.

Biondini, M. E., Patton, B. D. \& Nyren, P. E. 1998: Grazing intensity and ecosystem processes in a northern mixed-grass prairie, USA. Ecological Applications 8(2): 469-479.

Bobbink, R. \& Willems, J. H. 1987: Increasing dominance of B. pinnatum (L.) Beauv. in chalk grasslands: a threat to a species-rich ecosystem. Biological Conservation 40: 301-314.

Bonanomi, G. \& Allegrezza, M. 2004: Effetti della colonizzazione di Brachypodium rupestre (Host) Roemer et Schultes sulla diversità di alcune fitocenosi erbacee dell'Appennino centrale. Fitosociologia 41(2): 51-69.

Borhidi, A. 1995: Social behaviour types, the naturalness and relative ecological indicator values of the higher plants in the Hungarian flora. Acta Botanica Hungarica 39: 97-181.

Braun-Blanquet, J. 1964: Pflanzensoziologie. Grundzüge der vegetationskunde. 3. Aufl. Springer Ver., Wien-New York, pp. 865.

Buckland, S. M., Thompson, K., Hodgson, J. G. \& Grime, J. P. 2001: Grassland invasions: effects of manipulations of climate and management. Journal of Applied Ecology 38: 289-294.

Bullock, J. M., Franklin, J., Stevenson, M. J., Silvertown, J., Coulson, S. J., Gregory, S. J. \& 
Tofts, R. 2001: A plant trait analysis of responses to grazing in a long-term experiment. Journal of Applied Ecology 38: 253-267.

Campetella, G., Canullo, R. \& Bartha, S. 2004: Coenostate descriptors and spatial dependence in vegetation: Derived variables in monitoring forest dynamics and assembly rules. Community Ecology 5: 105-114.

Čarni, A. 2003: Vegetation of forest edges in the central part of Istria (Istria, northwestern Croatia). Natura Croatica 12(3): 131-140.

Čarni, A., Franjić, J., Šilc U. \& Škvorc, Ž. 2005: Floristical, ecological and structural diversity of vegetation of forest fringes of Northern Croatia along a climatic gradient. Phyton 45(2): 287-303.

Catorci, A. \& Gatti, R. 2010: Floristic composition and spatial distribution assessment of montane mesophilous grasslands in the central Apennines, Italy: a multi-scale and diachronic approach. Plant Biosystems 144(4): 793-804.

Catorci, A., Ottaviani, G., Ballelli S., \& Cesaretti, S. 2011b: Functional differentiation of Central Apennine grasslands under mowing and grazing disturbance regimes. Polish Journal of Ecology 59(1): 115-128.

Catorci, A., Ottaviani, G. \& Cesaretti, S. 2011a: Functional and coenological changes under different long-term management conditions in Apennine meadows (central Italy). Phytocoenologia 41(1): 45-58.

Collins, S. L., Knapp, A. K., Briggs, J. M., Blairs, J. M. \& Steinauer, E. M. 1998: Modulation of diversity by grazing and mowing in native tallgrass prairie. Science 280: 745-747.

de Bello, F., Lepš, J., Sebastià, M. T. 2006: Variations in species and functional plant diversity along climatic and grazing gradients. Ecography 29: 801-810.

de Bello, F., Lepš, J., Sebastià, M. T. 2007: Grazing effect on species and functional diversity along a climatic gradient. Journal of Vegetation Science 18: 25-34.

Decocq, G., Aubert, M., Dupont, F., Alard, D., Saguez, R., Wattez-Franger, A., De Foucault, B., Delelis-Dusollier, A. \& Bardat, J. 2004: Plant diversity in a managed temperate deciduous forest: understorey response to two silvicultural systems. Journal of Applied Ecology 41: 1065-1079.

Díaz, S. \& Cabido, M. 1997: Plant functional types and ecosystem function in relation to global changes. Journal of Vegetation Science 8: 463-474.

Díaz, S., Lavorel, S., McIntyre, S., Falczuk, V., Casanoves, S., Milchunas, D. G., Skarpe, C., Rusch, G., Sternberg, M., Noy-Meir, I., Landsberg, J., Zhang, W., Clark, H. \& Campbell, B. D. 2007: Plant traits responses to grazing - a global synthesis. Global Change Biology 13: 313-341.

Dullinger, S., Dirnböck, T. \& Grabherr, G. 2003: Pattern of shrub invasion into high mountain grasslands of the Northern calcareous Alps, Austria. Arctic, Antarctic, and Alpine Research 35(4): 434-441.

During, H. J. \& Willems, J. H. 1984: Diversity models as applied to a chalk grassland. Vegetatio 57: 103-114.

Frank, D. A. 2005: The interactive effects of grazing ungulates and aboveground production on grassland diversity. Oecologia 143: 629634.

Hirst, R. A., Pywell, R. F., Marrs, R. H. \& Putwain, P. D. 2005: The resilience of calcareous and mesotrophic grasslands following disturbance. Journal of Applied Ecology 42: 498506.

Hobbs, R. J. 1997: Can we use plant functional types to describe and predict responses to environmental change? In: Smith, T. A., Shugard, H. H. \& Woodward, F. I. (eds.): Plant Functional Types. Their Relevance to Ecosystem Properties and Global Change. Cambridge University Press, Cambridge, pp. 66-90.

Holling, C. S. (ed.) (1978). Adaptive Environmental Assessment and Management. Chichester, Wiley, pp. 377.

Hunt, R., Hodgson, J. G., Thompson, K., Bungener, P., Dunnett, N. P. \& Askew, A. P. 2004: A new practical tool for deriving a functional signature for herbaceous vegetation. Applied Vegetation Science 7: 163-170.

Kahmen, S., Poschlod, P. \& Schreiber, K. 2002: Conservation management of calcareous grasslands. Changes in plant species composition and response of functional traits during 25 years. Biological Conservation 104: 319-328.

Kaligarič, M. 1997: Rastlinstvo primorskega krasa in Slovenske Istre - Travniki in pašniki. Zgodovinsko društvo za južno primorsko. Znanstveno raziskovalno središče Republike Slovenije Koper, Koper, 111 pp.

Kaligarič, M., Culiberg, M. \& Kramberger, B. 2006: Recent vegetation history of the North 
Adriatic grasslands: expansion and decay of an anthropogenic habitat. Folia Geobotanica 41: 241-258.

Kaligarič, M. \& Poldini, L. 1997: Nuovi contributi per una tipologia fitosociologica delle praterie magre (Scorzoneretalia villosae H-ić 1975) del Carso nordadriatico. Gortania 19: 119-148.

Kelly, C. K. 1996: Identifying plant functional types using floristic data bases: ecological correlates of plant size. Journal of Vegetation Science 7: 417-424.

Kleyer, M. 1999: The distribution of plant functional types on gradients of disturbance intensity and resource supply in an agricultural landscape. Journal of Vegetation Science 10: 697-708.

Klimek, S., Richter gen. Kemmermann, A., Hofmann, M. \& Isselstein, J. 2006: Plant species richness and composition in managed grasslands: The relative importance of field management and environmental factors. Biological Conservation 134: 559-570.

Kolasa, J. \& Rollo, C. D. 1991: Introduction: the heterogeneity of heterogeneity, a glossary. In: Kolasa, J. \& Pickett, S. T. A. (eds.): Ecological Heterogeneity. Springer, New-York, pp. 1-23.

Lavorel, S., McIntyre, S., Landsberg, J. \& Forbes, T. D. A. 1997: Plant functional classifications: from general groups to specific groups based on response to disturbance. Trends in Ecology and Evolution 12: 474-478.

Luick, R. 1998: Ecological and socio-economic implications of livestock-keeping systems on extensive grasslands in south-western Germany. Journal of Applied Ecology 35: 979-982.

MacDonald, D., Crabtree, J. R., Wiesinger, G., Dax, T., Stamou, N., Fleury, P., Lazpita, J. G. \& Gibon, A. 2000: Agricultural abandonment in mountain areas of Europe: environmental consequences and policy response. Journal of Environmental Management 59: 47-69.

McIntyre, S., Díaz, S., Lavorel, S. \& Cramer, W. 1999: Plant functional types and disturbance dynamics - Introduction. Journal of Vegetation Science 10: 604-608.

Milchunas, D. G. \& Lauenroth, W. K. 1993: Quantitative effects of grazing on vegetation and soils over a global range of environments. Ecological Monographs 63: 327-366.

Mucina, H. L., Grabherr, G. \& Ellmauer, T. 1993: Die Pflanzengesellschaften Österreichs. Teil I. Anthropogene Vegetation - Gustav Fisher, $578 \mathrm{pp}$.
Myklestad, Á. \& Sxtersdal, M. 2004: The importance of traditional meadow management techniques for conservation of vascular plant species richness in Norway. Biological Conservation 118: 133-139.

Nikolić, T. (ed.) 2011: Flora Croatica Database, (URL http://hirc.botanic.hr/fcd). Prirodoslovno-matematički fakultet, Sveučilište u Zagrebu. (Faculty of Science, University of Zagreb).

Noble, I. \& Gitay, H. 1996: A functional classification for predicting the dynamics of landscapes. Journal of Vegetation Science 7: 329336.

Norderhaug, A., Ihse, M. \& Pedersen, O. 2000: Biotope patterns and abundance of meadow plant species in a Norwegian rural landscape. Landscape Ecology 15: 201-218.

Orloci, L. 1978: Multivariate analysis in vegetation research. W. Junk, The Hague, 481 pp.

Pärtel, M., Mändla, R. \& Zobel, M. 1999: Landscape history of a calcareous (alvar) grassland in Hanila, western Estonia during the last three hundred years. Landscape Ecology 14: 187-196.

Pignatti, S. 1982: Flora d'Italia. I-III - Edagricole, Bologna, 2302 pp.

Pillar, V. D. 1999: On the identification of optimal plant functional types. Journal of Vegetation Science 10: 631-640.

Podani, J. 2001: Syn-tax 2000 computer program for data analysis in ecology and systematics. Budapest.

Poldini, L. 1980: Übersicht über die Vegetation des Karstes von Triest und Görz (NO-Italien). Studia Geobotanica 1(1): 79-130.

Poldini, L. 1985: Note ai margini della vegetazione carsica. Studia Geobotanica 5: 39-48.

Poldini, L. 1989: La vegetazione del Carso isontino e triestino. Studio del paesaggio vegetale tra Trieste, Gorizia e i territori adiacenti. Edizioni Lint Trieste, 315 pp.

Poldini, L. \& Oriolo, G. 1994. La vegetazione dei prati da sfalcio e dei pascoli intensivi (Arrhenatheretalia e Poo-Trisetetalia) in Friuli (NE Italia). Studia Geobotanica 14, suppl. 1: 3-48.

Poschlod, P. \& Wallis De Vries, M. F. 2002: The historical and socioeconomic prospective of calcareous grasslands-lessons from the distant and recent past. Biological Conservation 104: 361-376.

Robinson, R. A. \& Sutherland, W. J. 2002: Postwar changes in arable farming and biodiver- 
sity in Great Britain. Journal of Applied Ecology 39: 157-176.

Scheiner, S. M. 1992: Measuring pattern diversity. Ecology 73(5): 1860-1867.

Sebastià, M. T., de Bello, F., Puig, L. \& Taull, M. 2008: Grazing as a factor structuring grasslands in the Pyrenees. Applied Vegetation Science 11: 215-222.

Tscharntke, T., Klein, A. M., Kruess, A., SteffanDewenter, I. \& Thies, C. 2005: Landscape perspectives on agricultural intensification and biodiversity - ecosystem service management. Ecology Letters 8(8): 857-874.

van der Maarel, E. 1979: Trasformation of coverabundance values in phytosociology and its effects on community similarity. Vegetatio 39 : 97-144.

van Dijk, G. 1991: Half-natuurlijke graslanden in Europa verdwijnen. Natuur en Milieu 15(9): 8-13.

Vitanzi, A., Paura, B. \& Catorci, A. 2009: Forest syntaxa spatial distribution hierarchical modelling: preliminary assessment of a Central Apennine (Italy) landscape. Sauteria 18: 311322.

Vitasović Kosić, I. 2011: Grasslands ScorzoneroChrysopogonetalia order on the Ćićarija: Flora, Vegetation and Feed value. Dissertation (PhD), University of Zagreb, Faculty of Agriculture, pp. 1-247.

Vitasović Kosić, I., Tardella F. M., Ruščić M. \& Catorci, A. 2011: Assessment of floristic diversity, functional composition and management strategy of North Adriatic pastoral landscape (Croatia). Polish Journal of Ecology 59(4): 765-776.

Willems, J. H. 1990: Calcareous grasslands in Continental Europe. In: Hillier, S. H., Walton, D. W. H. \& Wells D. A. (eds.): Calcareous grasslands: ecology and management. Bluntisham Books, Bluntingham, pp. 3-10.

Wilson, E. J., Wells, T. C. E. \& Sparks, T. H. 1995: Are calcareous grasslands in the UK under threat from nitrogen deposition? An experimental determination of a critical load. Journal of Ecology 83: 823-832.

Wilson, W. L., Abernethy, V. J., Murphy, K. J., Adam, A., McCracken, D. I., Downie, I. S., Foster, G. N., Furness, R. W., Waterhouse, A. \& Ribera, I. 2003: Prediction of plant diversity response to land-use change on Scottish agricultural land. Agriculture, Ecosystems and Environment 94: 249-263.
Zervas, G. 1998: Quantifying and optimizing grazing regimes in Greek mountain systems. Journal of Applied Ecology 35: 983-986.

\section{APPENDIX}

\section{Localities, date of the relevés and accidental species}

Table 1: Danthonio-Scorzoneretum villosae Ht. \& H-ić (1956) 1958

Locality and date of the relevés: rel. $1-5-$ Brest pod Učkom (15/06/2009); rel. 6-8 - Semić (08/ 07/2009); rel. 9 - Žbevnica (23/06/2009); rel. 1011 - Semić, meadow (08/07/2009); rel. 12 - Slum, meadow (23/06/2009); rel. 13 - Slum, meadow (08/09/2009); rel. 14 - Gregurinčići, meadow (09/09/2009); rel. 15 - St. Grgur (10/09/2009); rel. 16 - Boljunski Katun, meadow (09/09/2009); rel. 17 - Trošti, meadow (09/09/2009).

Accidental species: rel. 4 - Clematis vitalba, +; rel. 6 - Carduus pycnocephalus, +; Silene latifolia subsp. alba, +; rel. 7 - Rumex crispus, +; Erigeron annuus, +; Briza minor, +; Allium sp., +; rel. $8-\mathcal{J} u$ niperus communis, +; Pinus nigra, +; rel. $10-$ Luzula multiflora, +; rel. 11 - Acinos arvensis, +; rel. 12 - Cerastium arvense subsp. strictum, +; rel. 13 - Carduus nutans, 1; Cirsium arvense, +; rel. 15 Scolymus hispanicus, 2.

Table 2: Carici humilis-Centaureetum rupestris Ht. 1931

Brachypodium rupestre variant (rell. 15-40)

Locality and date of the relevés: rel. 1 - Brest pod Učkom (15/06/2009); rel. 2-4 - Slum, near Genetic center (15/06/2009); rel. 5 - Slum, pasture on the hill (15/06/2009); rel. 6 - Jelovice, pasture on the hill (17/06/2009); rel. 7-8 - Slum, near Genetic center (23/06/2009); rel. 9 - Slum, near Genetic center (08/09/2009); rel. 10 - Žbevnica (10/07/2009); rel. 11 - Žbevnica (23/06/2009); rel. 12-13 - Brgudac-Lanišće (08/07/2009); rel. 14 - Lanišće, abandoned pasture (08/07/2009); rel. 15-19 - Jelovice (16/06/2009); rel. 20-21 Vodice (16/06/2009); rel. 22 - Vodice, abandoned pasture (16/06/2009); rel. 23 - Jelovice, abandoned pasture in the village (17/06/2009); rel. 24 - Jelovice, abandoned grassland (17/06/2009); rel. 25 - Jelovice, abandoned pasture, dolines (17/06/2009); rel. 26 - Jelovice, abandoned pasture (17/06/2009); rel. 27 - Jelovice, dolines, succession with Laserpitium siler (17/06/2009); rel. 28 
- Jelovice, dolines, succession (17/06/2009); rel. 29 - Jelovice-Vodice, main road (17/06/2009); rel. 30 - Jelovice-Vodice, main road, $1 \mathrm{~km}$ futher than rel. 29 (17/06/2009); rel. 31 - Dane-Brest under Žbevnica (10/07/2009); rel. 32 - Vodice, pasture (08/07/2009); rel. 33 - Vodice, pasture (08/07/2009); rel. 34 - Vodice, pasture (08/ 07/2009); rel. 35 - Lanišće, abandoned pasture (09/07/2009); rel. 36-37 - Račja vas, abandoned grassland (09/07/2009); rel. 38-39 - Račja vasRašpor, abandoned pasture (09/07/2009); rel. 40 - Rašpor-Trstenik (09/07/2009).

Accidental species: rel. 5 - Viola odorata, + ; rel. 6 - Viola odorata, +; rel. 7 - Cerastium arvense subsp. strictum, +; Carduus nutans, +; rel. $8-C_{e-}$ rastium arvense subsp. strictum, +; rel. $9-$ Dorycnium hirsutum, +; rel. 12 - Daucus carota, +; rel. 15 - Cirsium arvense, + ; Poa bulbosa, + ; rel. $16-$ Rhinanthus glacialis, +; rel. 17 - Sorbus aucuparia, +; Cirsium arvense, +; rel. 18 - Sorbus aucuparia, +; Poa bulbosa, +; rel. 22 - Rhamnus saxatilis, +; rel. 23 - Rhamnus saxatilis, +; Ajuga reptans, +; Convolvulus arvensis, +; rel. 25, 28 - Verbascum pulverulentum, + ; rel. 29 - Cytisus nigricans, + ; Potentilla reptans, +; Thlaspi perfoliatum, +; Gentiana lutea subsp. symphyandra, +; rel. 30 - Potentilla reptans, +; Gentiana lutea subsp. symphyandra, +; rel. 31 - Cytisus nigricans, +; Acinos arvensis, +; rel. 32 - Silene latifolia subsp. alba, + ; rel. 33 - Silene latifolia subsp. alba, + ; Clematis vitalba,+ ; rel. $34-$ Acer campestre, + ; Scolymus hispanicus, +; Pastinaca sativa, + ; rel. 35 - Quercus cerris +; rel. 36 - Apera spica-venti, + ; rel. 37 - Acer campestre, + ; Fraxinus excelsior, +; rel. 38 - Fraxinus excelsior, +; Rhinanthus glacialis, +; Vicia villosa, +; rel. 39 - Daucus carota, + ; rel. $40-$ Apera spica-venti, + ; Thlaspi perfoliatum, + .

Table 3: Anthoxantho-Brometum erecti Poldini 1980 Locality and date of the relevés: rel. 1 - Vodice, abandoned meadow, karst field (16/06/2009); rel. 2 - Vodice, abandoned meadow (16/06/2009); rel. 3 - Jelovice, meadow (17/06/2009); rel. 4 - Dane, abandoned meadow (17/06/2009); rel. 5 - Dane, abandoned pasture (17/06/2009); rel. 6 - Brgudac, abandoned meadow, village (08/07/2009); rel. 7 - Brgudac, abandoned meadow (08/07/2009); rel. 8 - Račja vas, meadow along the main road (09/07/2009); rel. 9 - Račja vas, abandoned pasture, near the cemetery (09/07/2009); rel. 10 - Klenovščak, meadow along the road (09/07/2009); rel. 11 Vodice-Dane, abandoned meadow (09/07/2009); rel. 12 - Vodice-Dane, abandoned pasture (09/07/2009); rel. 13 - Jelovice, abandoned pasture (10/07/2009); rel. 14 - Jelovice, wetter meadow (10/07/2009); rel. 15 - Klenovščak, abandoned meadow, dolines (10/07/2009); rel. 16 - Klenovščak, dolines (10/07/2009).

Accidental species: rel. 1 - Cornus mas, +; Rhamnus saxatilis, +; Stachys recta, +; rel. 2 - Gentiana lutea subsp. symphyandra, +; Inula ensifolia, +; rel. 3 - Echium vulgare, + ; Crepis sancta, + ; Linum narbonense, +; Dianthus sanguineus, +; Linum tenuifolium, +; Hieracium bahuinii, +; Peucedanum cervaria, +; Calamintha menthifolia, +; rel. $4-S i$ lene vulgaris, +; Lilium bulbiferum, +; Allium sp., +; rel. 5 - Luzula multiflora, +; Pinus nigra, +; rel. 6 - Carduus pycnocephalus, +; Picris hieracioides, +; rel. 7 - Cichorium intybus, +; Clematis vitalba, +; rel. 8 - Knautia purpurea, +; rel. 9 - Dianthus monspessulanum, +; rel. 10 - Paeonia mascula, +; Leucanthemum vulgare, +; rel. 12 - Aristolochia clematitis, +; Prunus spinosa, 1; Rhamnus fallax, +; rel. 13 - Plantago holosteum, +; Laserpitium siler, +; rel. 14 - Campanula pyramidalis, +; Pseudolysimachion spicatum subsp. barrelieri, +; rel. 15 - Potentilla reptans, +; rel. 16 - Allium sphaerocephalon, +.
Received 9. 5. 2011

Revision received 16. 11. 2011

Accepted 21. 11. 2011 
Table 1: Danthonio-Scorzoneretum villosae Horvat \& Horvatić in Horvatić 1958.

Tabela 1: Danthonio-Scorzoneretum villosae Horvat \& Horvatić in Horvatić 1958.

\begin{tabular}{|c|c|c|c|c|c|c|c|c|c|c|c|c|c|c|c|c|c|c|}
\hline Relevé no. & 1 & 2 & 3 & 4 & 5 & 6 & 7 & 8 & 9 & 10 & 11 & 12 & 13 & 14 & 15 & 16 & 17 & \\
\hline Relevé no. in Figure 1 & 1 & 4 & 2 & 3 & 5 & 31 & 32 & 33 & 68 & 34 & 35 & 66 & 69 & 72 & 73 & 70 & 71 & \\
\hline Altitude (m a.s.l.) & 661 & 661 & 661 & 661 & 660 & 522 & 516 & 527 & 888 & 521 & 531 & 493 & 493 & 256 & 256 & 233 & 661 & \\
\hline Slope $\left(^{\circ}\right)$ & 0 & 0 & 0 & 0 & 0 & 7 & 10 & 0 & 10 & 0 & 0 & 3 & 3 & 0 & 0 & 0 & 0 & \\
\hline Aspect & 0 & 0 & 0 & 0 & 0 & E & $\mathrm{E}$ & 0 & NW & 0 & 0 & SSW & W & 0 & 0 & 0 & 0 & \\
\hline Relevé area $\left(\mathrm{m}^{2}\right)$ & 100 & 100 & 100 & 100 & 100 & 100 & 100 & 100 & 25 & 100 & 100 & 25 & 100 & 100 & 100 & 100 & 100 & \\
\hline Cover $(\%)$ & 100 & 100 & 100 & 100 & 100 & 90 & 97 & 100 & 100 & 100 & 100 & 100 & 100 & 100 & 90 & 98 & 100 & \\
\hline Landform & 㭉 & $\underset{\pi}{\rightleftarrows}$ & $\underset{\pi}{\rightleftarrows}$ & $\underset{\leftrightarrows}{\rightleftarrows}$ & $\stackrel{\Xi}{\rightleftarrows}$ & 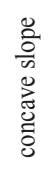 & 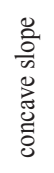 & $\underset{\mathbb{G}}{\mathbb{\pi}}$ & 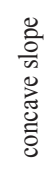 & $\underset{\pi}{\rightleftarrows}$ & $\stackrel{\pi}{\rightleftarrows}$ & $\stackrel{\Xi}{\rightleftarrows}$ & $\underset{\pi}{\frac{\pi}{\pi}}$ & $\underset{\leftrightarrows}{\rightleftarrows}$ & $\underset{t}{\mathbb{E}}$ & $\underset{\pi}{\rightleftarrows}$ & $\stackrel{\Xi}{\rightleftarrows}$ & $\begin{array}{l}\dot{0} \\
\dot{0} \\
\dot{D} \\
\dot{D}\end{array}$ \\
\hline Grassland management & 先 & 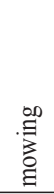 & 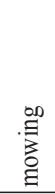 & 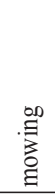 & 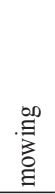 & 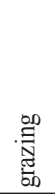 & 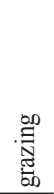 & 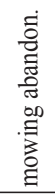 & 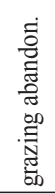 & 告 & 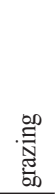 & . & . & 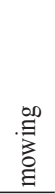 & 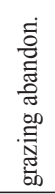 & . & . & \\
\hline
\end{tabular}

Characteristic and differential species of Danthonio-Scorzoneretum villosae association

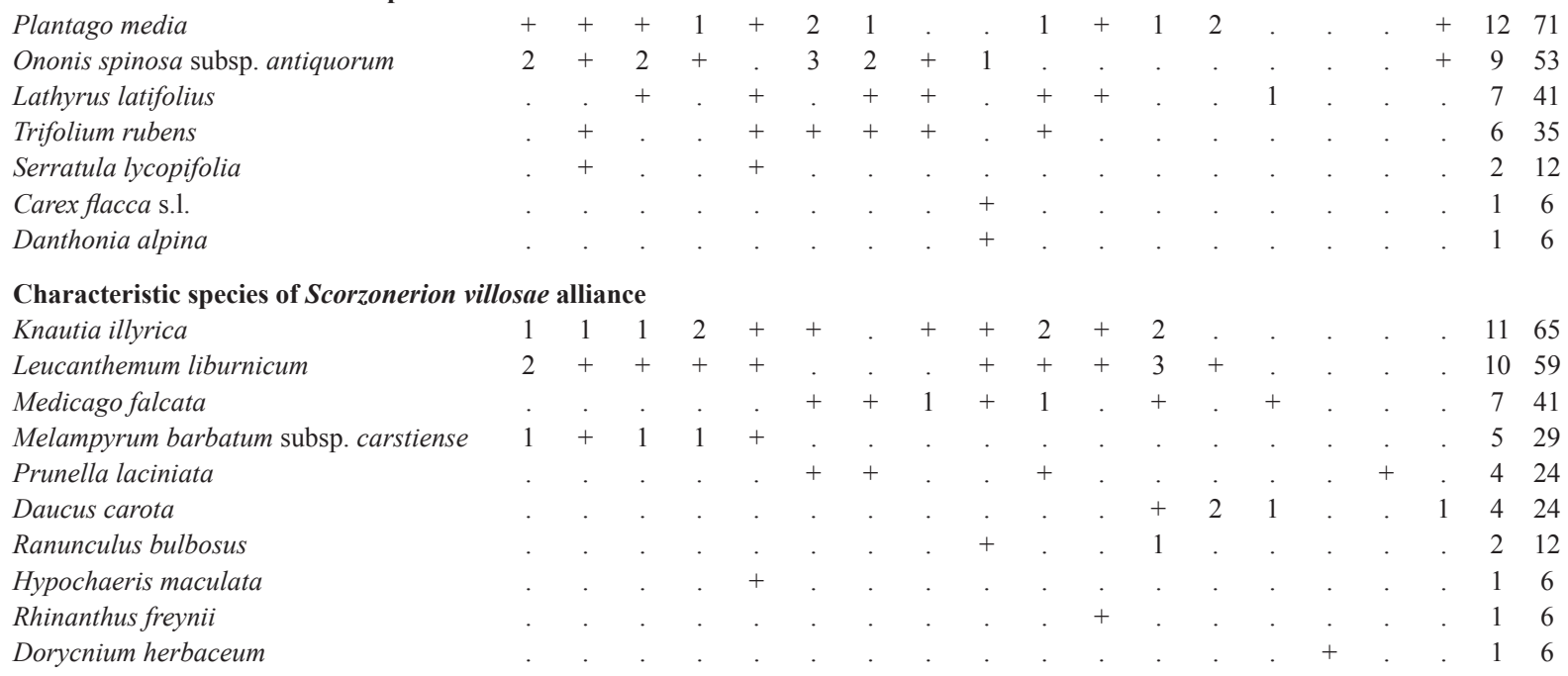

Characteristic and differential species of Scorzoneretalia villosae order

Salvia pratensis

Festuca rupicola

Chrysopogon gryllus

Koeleria splendens

Bromus condensatus

Scorzonera villosa

Polygala nicaeensis

Lotus corniculatus subsp. hirsutus

Globularia punctata

Thymus longicaulis

Cirsium acaule

Pseudolysimachion spicatum subsp. barrelieri

Galium lucidum

Inula hirta

Centaurea rupestris

Stachys subcrenata

Carex humilis

Muscari botryoides

\begin{tabular}{|c|c|c|c|c|c|c|c|c|c|c|c|c|c|c|c|c|c|c|}
\hline 1 & 1 & 2 & 1 & 1 & 2 & 1 & + & + & 2 & 1 & & 2 & 1 & + & 1 & 1 & 16 & 94 \\
\hline+ & 1 & + & + & 2 & 2 & 1 & . & + & + & 1 & & . & . & . & . & . & 10 & 59 \\
\hline & . & . & . & . & 1 & + & 2 & 4 & 1 & 3 & & & . & + & 4 & 1 & 9 & 53 \\
\hline+ & + & . & . & + & + & + & 1 & . & 3 & 2 & • & & . & . & 2 & & 9 & 53 \\
\hline 2 & 1 & 1 & 3 & 3 & 2 & . & 1 & 2 & . & . & + & & . & . & & . & 9 & 53 \\
\hline 3 & 2 & 4 & 1 & 1 & . & . & . & . & 2 & + & . & . & . & . & & . & 7 & 41 \\
\hline 1 & + & + & + & + & . & . & + & + & . & . & & . & . & . & . & . & 7 & 41 \\
\hline 1 & + & + & + & + & . & . & . & . & + & + & . & . & . & . & . & . & 7 & 41 \\
\hline 1 & + & . & . & + & . & . & . & . & + & + & & . & . & . & + & . & 6 & 35 \\
\hline+ & + & + & . & + & . & . & . & + & . & . & . & . & . & . & . & . & 5 & 29 \\
\hline 1 & + & + & . & 2 & . & . & . & . & . & . & . & . & . & . & . & . & 4 & 24 \\
\hline . & . & . & . & . & 1 & + & . & . & . & . & . & . & . & . & 1 & . & 3 & 18 \\
\hline . & . & . & . & . & + & . & 1 & . & & . & & . & 2 & . & . & . & 3 & 18 \\
\hline . & . & . & . & + & . & . & + & . & . & . & $\cdot$ & + & . & . & . & . & 3 & 18 \\
\hline • & . & . & . & . & . & . & . & . & . & . & & . & + & + & + & . & 3 & 18 \\
\hline . & + & . & 2 & + & . & . & . & . & . & . & . & . & . & . & . & . & 3 & 18 \\
\hline & . & . & . & . & . & + & 1 & . & . & . & . & . & . & . & 1 & . & 3 & 18 \\
\hline & . & . & + & . & . & . & . & . & . & . & $\cdot$ & . & . & . & + & . & 2 & 12 \\
\hline
\end{tabular}


Relevé no.

\begin{tabular}{llllllllllllllllll}
1 & 2 & 3 & 4 & 5 & 6 & 7 & 8 & 9 & 10 & 11 & 12 & 13 & 14 & 15 & 16 & 17 & Pres. Fr. $\%$ \\
\hline
\end{tabular}

Centaurea cristata subsp. tommasinii

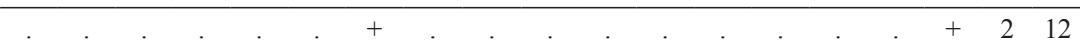

Centaurea triumfettii subsp. adscendens

Leontodon crispus

Buphthalmum salicifolium

Potentilla alba

Gentiana tergestina

Potentilla tommasiniana

Centaurea bracteata

Carlina acaulis

Genista sylvestris

Narcissus radiiflorus

Inula ensifolia

Potentilla australis

Allium senescens subsp. montanum

Euphorbia nicaeensis

Asperula cynanchica

Characteristic species of Festuco-Brometea class

Scabiosa triandra

Anthyllis vulneraria

Medicago lupulina s.1.

Hippocrepis comosa

Filipendula vulgaris

Briza media

Trifolium campestre

Vicia cracca

Bromus erectus

Lotus corniculatus

Onobrychis viciifolia

Thymus pulegioides

Teucrium chamaedrys

Sanguisorba minor subsp. muricata

Brachypodium rupestre

Tragopogon pratensis

Orchis morio

Satureja montana subsp. montana

Polygala vulgaris

Galium verum

Eryngium amethystium

Euphorbia cyparissias

Orchis militaris

Galium corrudifolium

Festuca valesiaca

Potentilla heptaphylla

Trifolium montanum

Linum catharticum

Knautia purpurea

Asperula aristata s.1.

Transgressive species from Molinio-Arrhenatheretea class

Plantago lanceolata

Achillea millefolium

Trifolium pratense subsp. pratense

Poa pratensis

Prunella vulgaris

Trisetum flavescens

Dactylis glomerata subsp. glomerata

Centaurea jacea

Trifolium repens subsp. repens

Arrhenatherum elatius subsp. elatius

$\begin{array}{cccccccccccccccccccc}+ & + & + & 1 & . & 1 & + & + & + & + & + & + & 2 & + & . & . & + & 14 & 82 \\ + & . & . & 2 & + & 2 & 2 & + & + & + & + & + & . & + & + & . & + & 13 & 76 \\ 3 & 1 & + & + & 3 & . & 2 & . & + & 1 & + & 1 & 1 & . & . & . & . & 11 & 65 \\ + & + & . & + & + & + & + & 1 & 1 & . & . & 1 & . & . & . & . & . & 9 & 53 \\ . & . & . & . & . & . & + & + & . & . & . & . & + & + & . & . & + & 5 & 29 \\ + & 1 & + & + & 1 & . & . & . & . & . & . & . & . & . & . & . & . & . & 5 & 29 \\ . & . & . & . & . & . & 1 & 1 & 1 & . & . & + & . & 4 & . & . & . & 5 & 29 \\ . & . & . & . & . & . & . & . & + & . & . & . & + & 3 & + & . & . & 4 & 24 \\ . & . & . & . & . & . & 2 & . & . & 1 & . & + & . & . & . & . & . & 3 & 18 \\ . & . & . & . & . & . & . & 1 & . & . & . & 4 & 2 & . & . & . & . & 3 & 18\end{array}$


Relevé no.

Plantago major

Lathyrus pratensis

Crepis biennis

Colchicum autumnale

Tragopogon orientalis

Holcus lanatus

Tragopogon porrifolius

Plantago altissima

Betonica officinalis subsp. serotina

Anthoxanthum odoratum

Stellaria graminea

Transgressive species from Trifolio-Geranietea sanguinei class

Trifolium alpestre

Inula salicina

Chamaecytisus hirsutus

Campanula rapunculus

Lilium bulbiferum

Scorzonera hispanica

Peucedanum oreoselinum

Orobanche lutea

Geranium sanguineum

Seseli libanotis

Peucedanum cervaria

Dictamnus albus

Knautia drymeia

\section{Companions}

Medicago sativa

Helianthemum salicifolium

Dactylis glomerata subsp. hispanica

Picris hieracioides

Sedum acre

Dorycnium hirsutum

Carex sp.

Convolvulus arvensis

Pastinaca sativa

Galium mollugo

Crepis sancta

Rosa canina

Calamagrostis arundinacea

Cichorium intybus

Senecio erucifolius

Elymus repens

Vicia angustifolia

Vicia sativa

Rubus caesius

Quercus cerris

Stellaria holostea

Petrorhagia saxifraga

Aira elegantissima

Filago vulgaris

Dorycnium pentaphyllum

Danthonia decumbens

Euphorbia palustris

Helleborus multifidus subsp. istriacus

Hypericum hirsutum

Poa bulbosa

Accidental species

\begin{tabular}{|c|c|c|c|c|c|c|c|c|c|c|c|c|c|c|c|c|c|}
\hline 2 & 3 & 4 & & 0 & & & & 10 & 11 & 12 & 13 & 14 & 15 & 16 & 17 & Pres. & \\
\hline . & + & . & . & . & . & 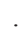 & & . & . & . & + & . & . & . & . & 2 & 12 \\
\hline . & . & + & + & . & . & . & . & . & . & . & . & . & . & . & . & 2 & 12 \\
\hline . & . & . & . & . & . & . & + & . & . & + & . & . & 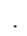 & . & . & 2 & 12 \\
\hline . & . & + & . & . & . & . & . & . & . & . & . & . & r. & . & . & 1 & 6 \\
\hline . & . & . & . & . & . & 1 & . & . & . & . & . & . & . & . & . & 1 & 6 \\
\hline . & . & . & . & . & . & . & + & . & . & . & . & . & . & . & . & 1 & 6 \\
\hline . & . & . & . & . & . & . & . & . & . & . & . & . & . & . & + & 1 & 0 \\
\hline . & . & . & . & . & . & . & . & . & . & . & . & + & . & . & . & 1 & 6 \\
\hline . & . & . & . & . & . & . & . & . & . & . & . & . & . & + & . & 1 & 6 \\
\hline . & . & . & . & . & . & . & 1 & . & . & . & . & . & . & . & . & 1 & \\
\hline . & . & . & . & + & . & . & . & . & . & . & . & . & . & . & . & 1 & \\
\hline
\end{tabular}
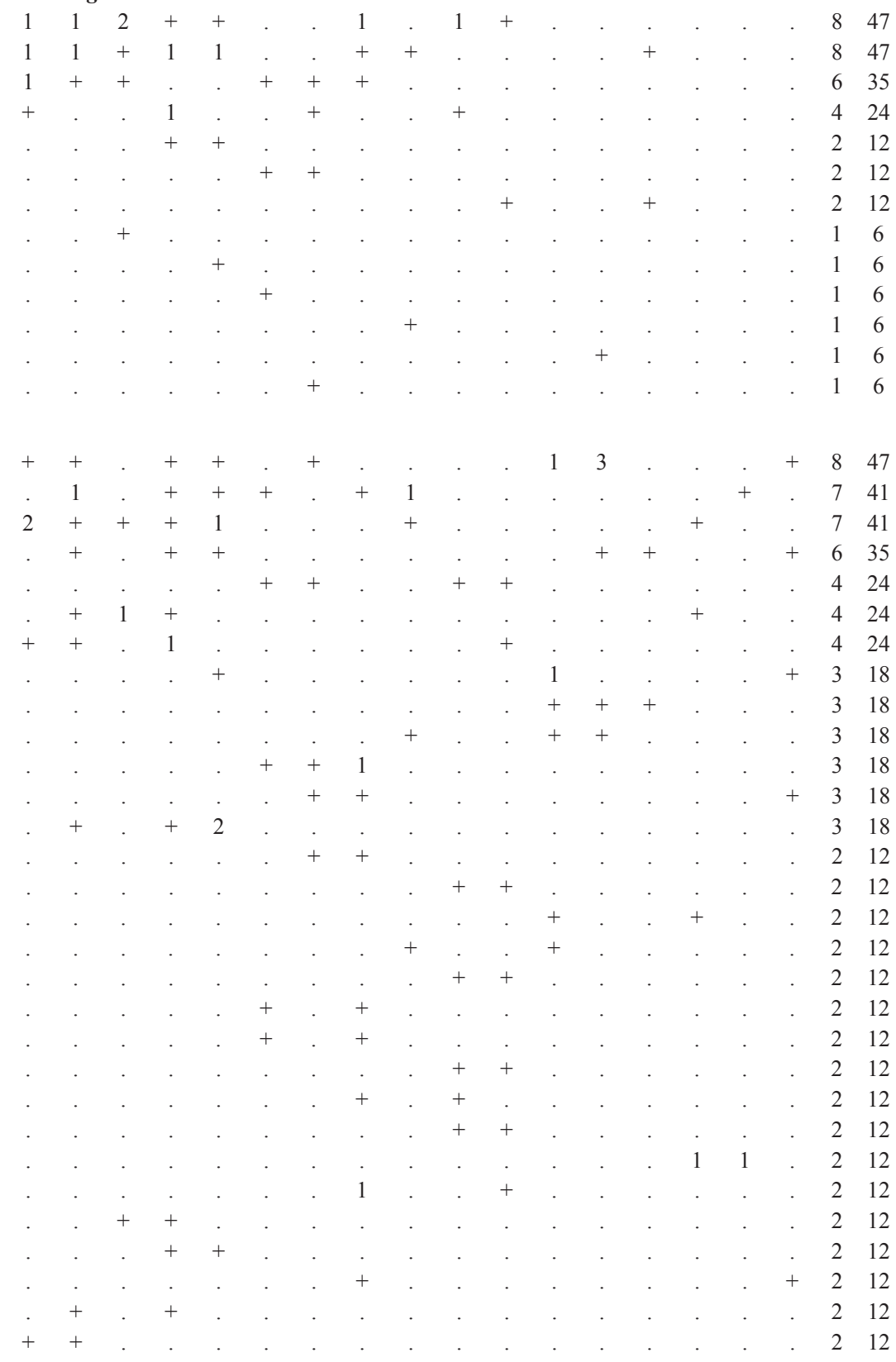

$\begin{array}{lllllllllllllllll}0 & 0 & 0 & 1 & 0 & 2 & 4 & 2 & 0 & 1 & 1 & 1 & 2 & 0 & 1 & 0 & 0\end{array}$ 


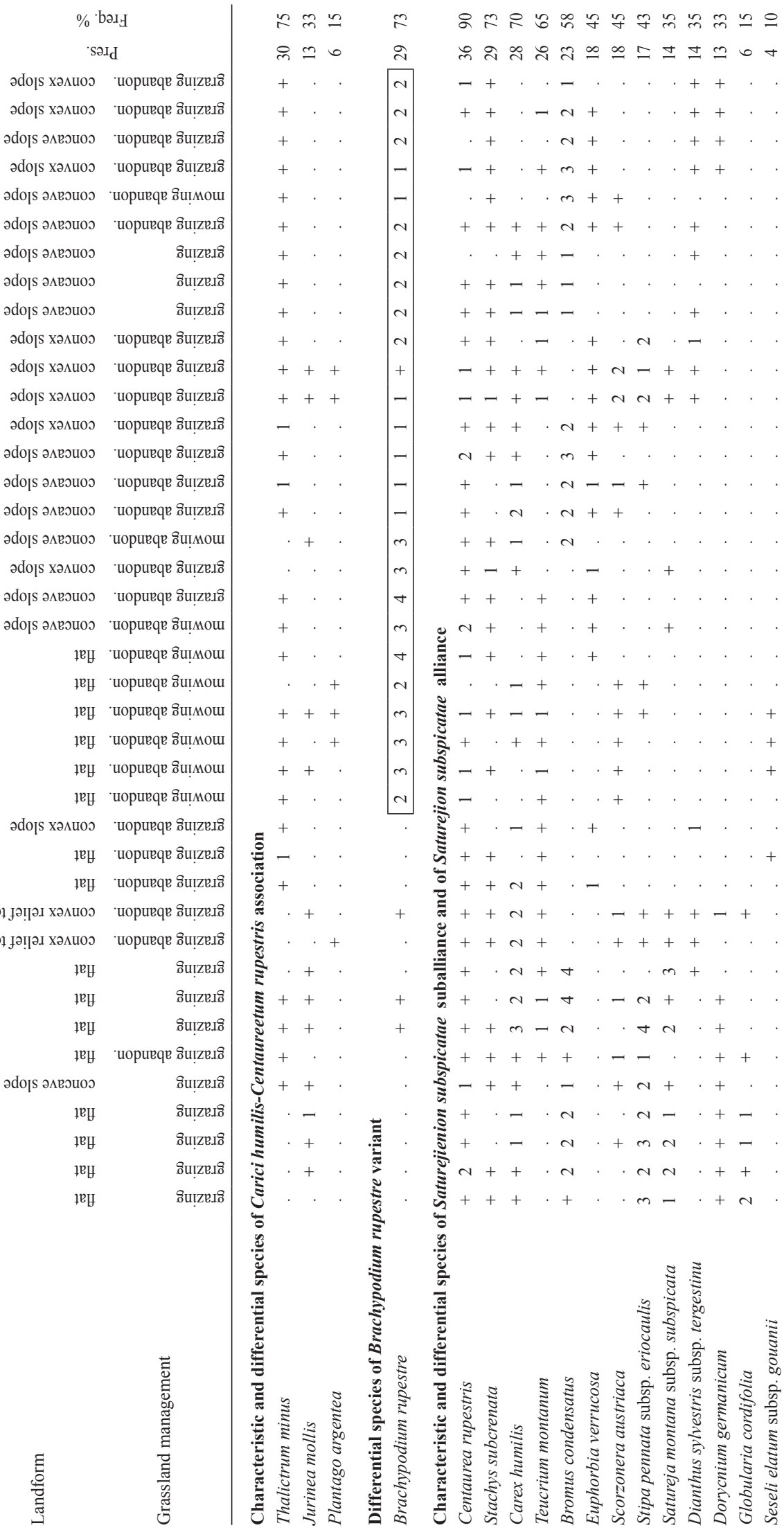




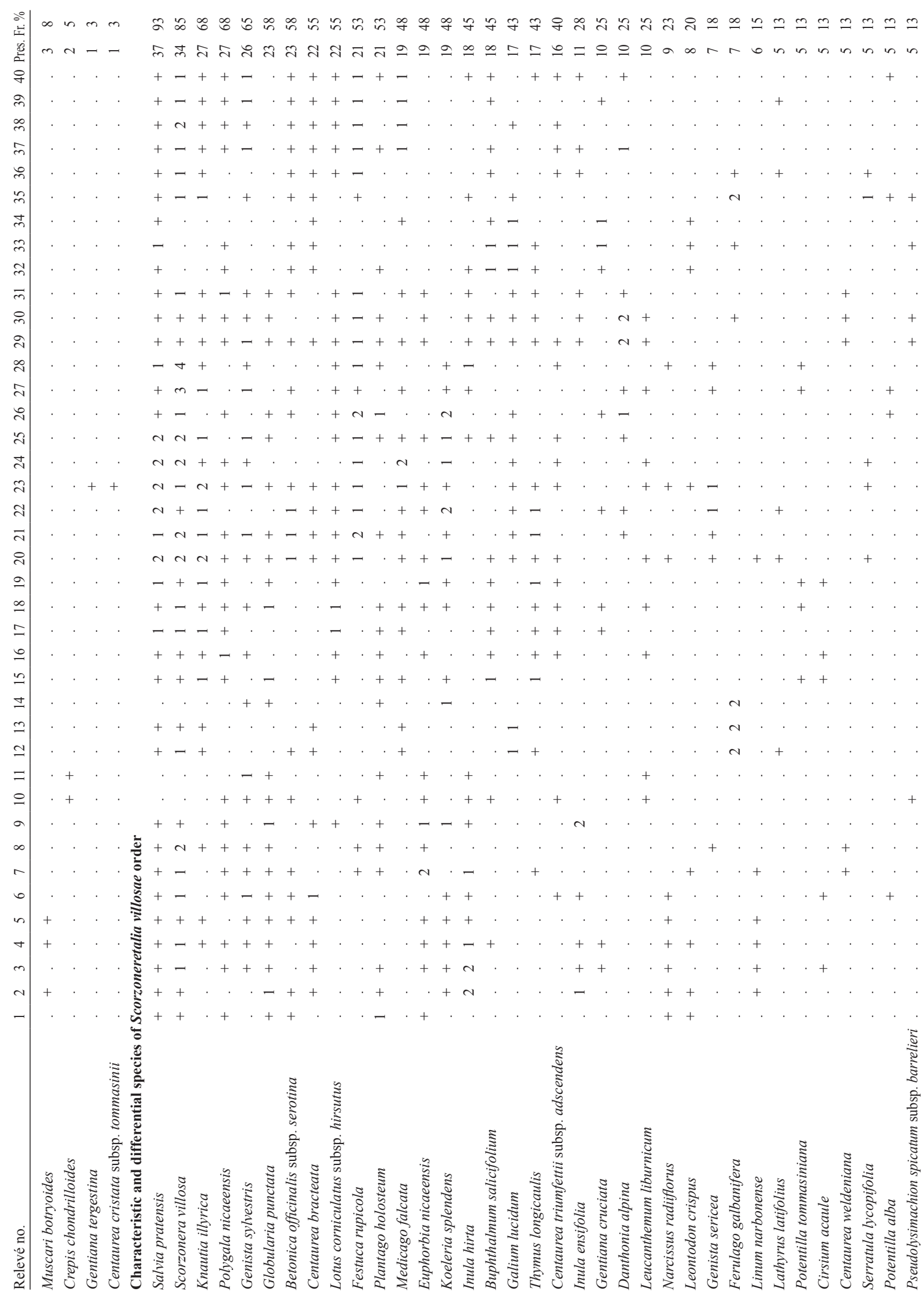




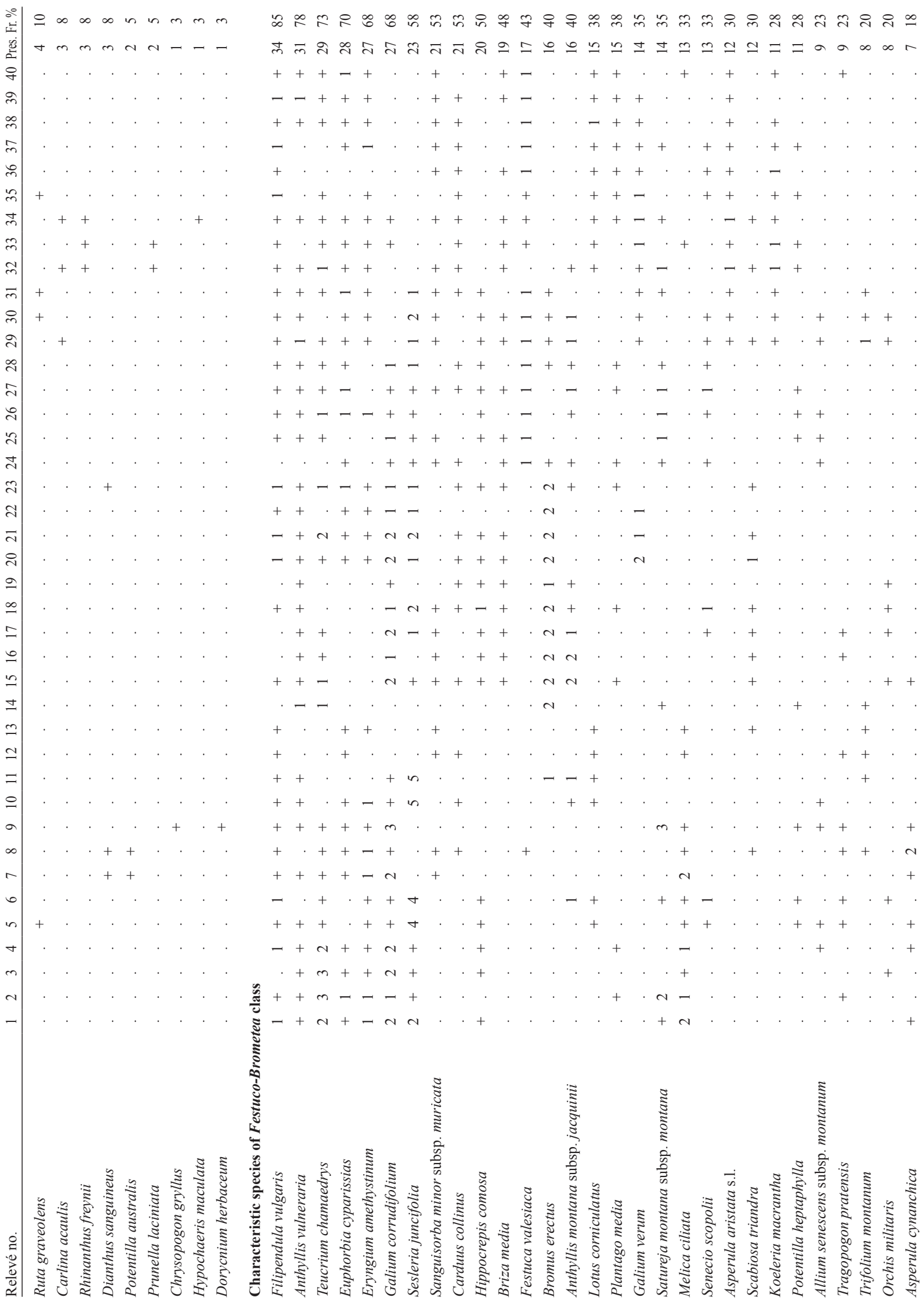




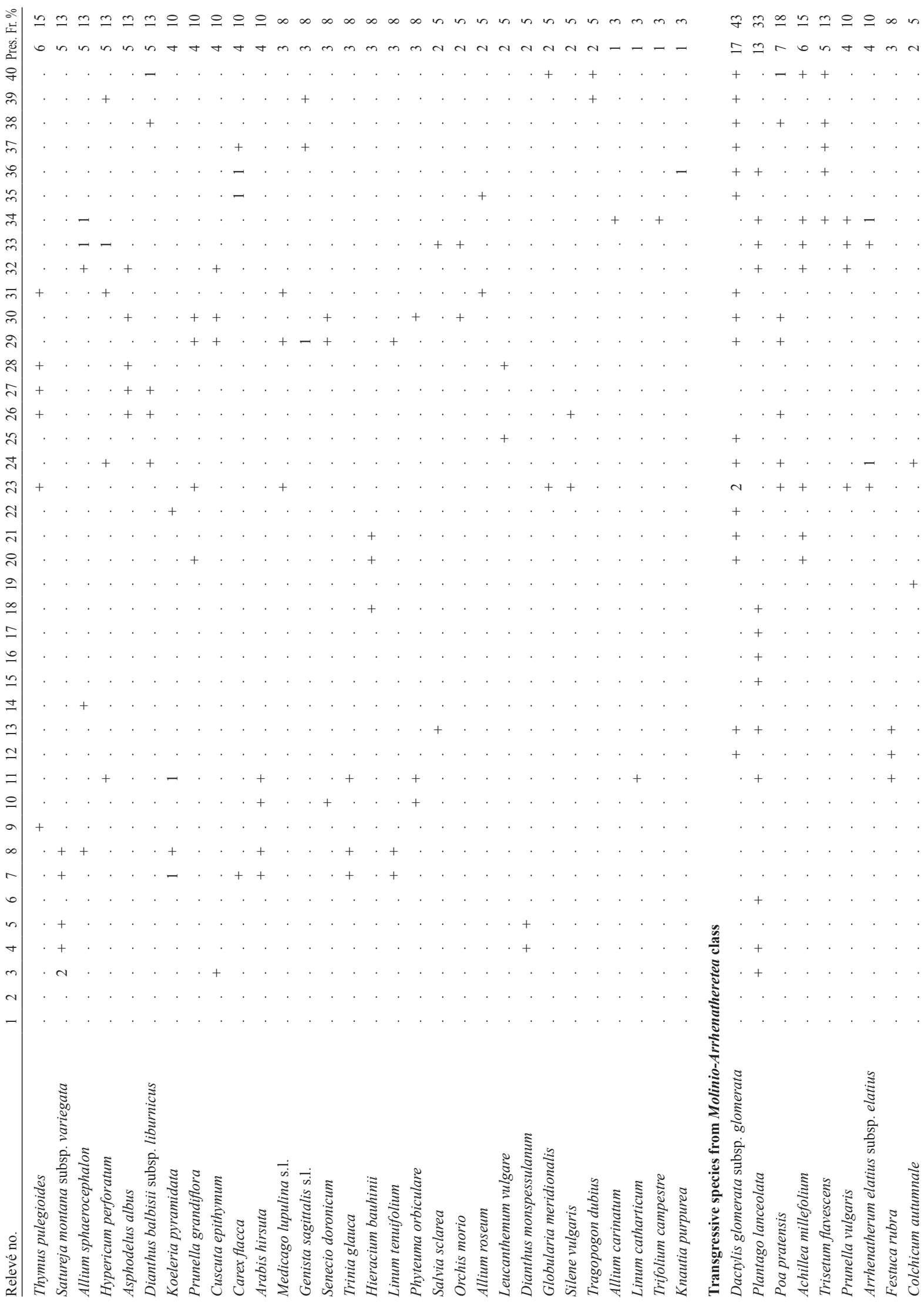




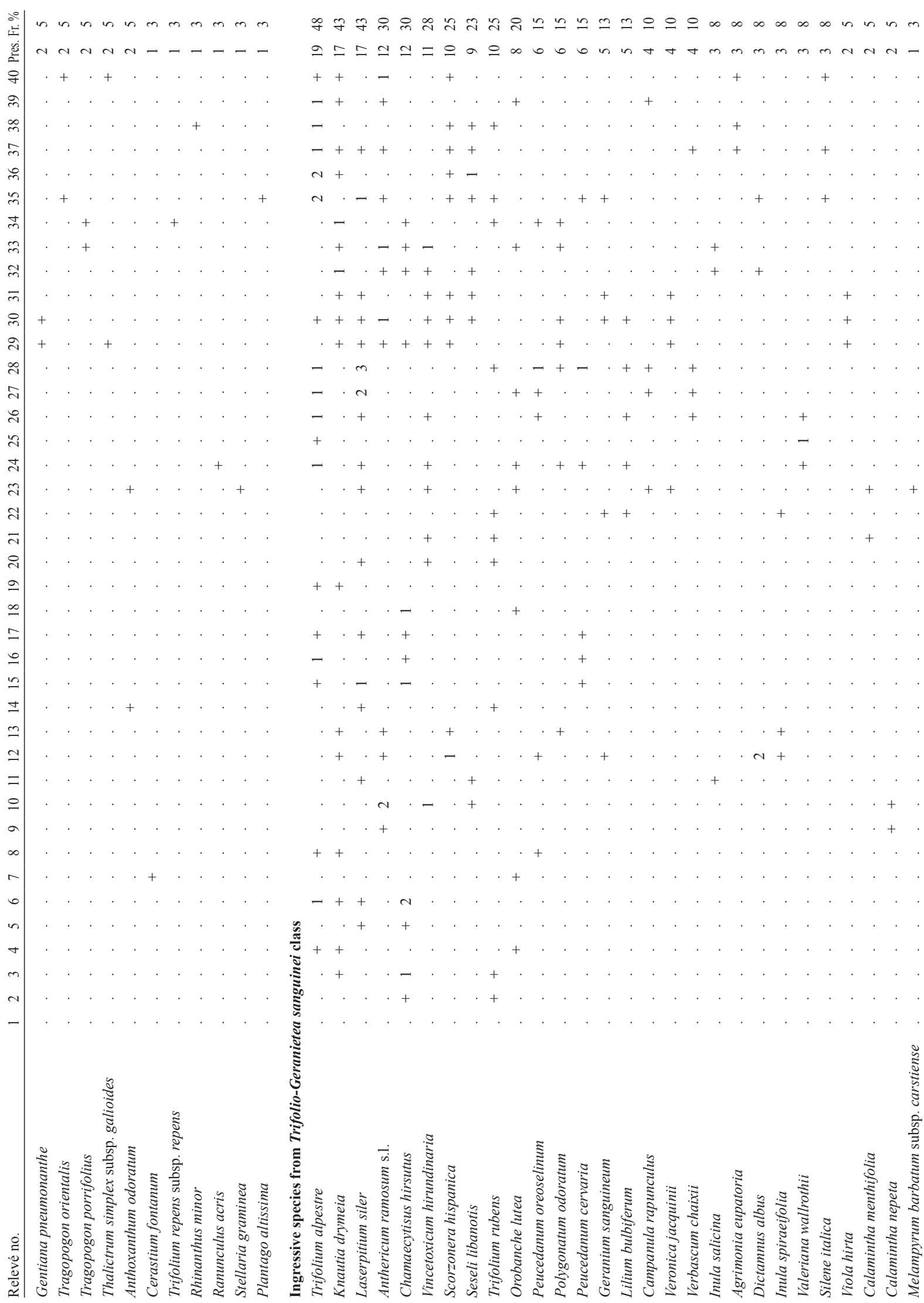



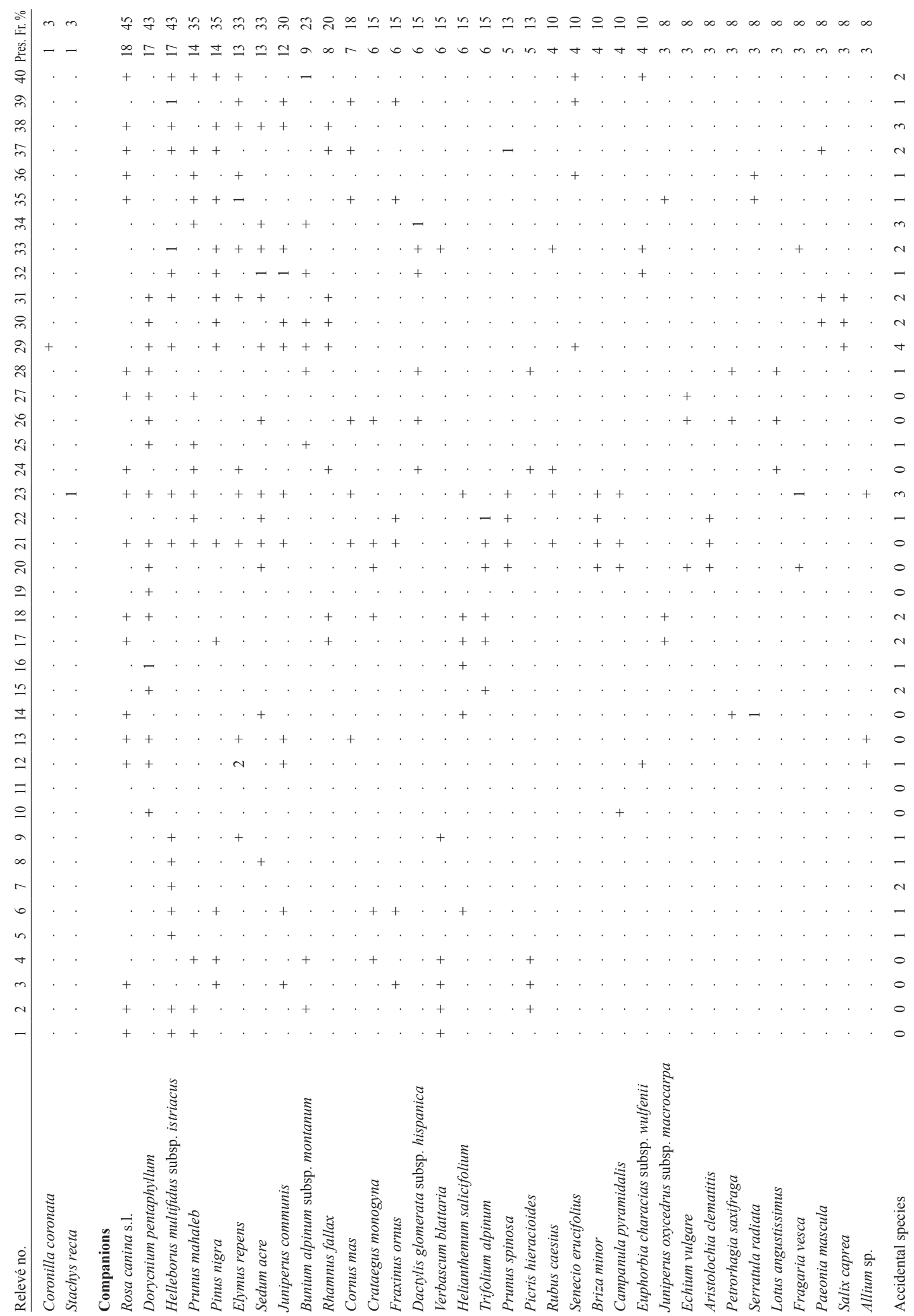
Table 3: Anthoxantho-Brometum erecti Poldini 1980.

Tabela 3: Anthoxantho-Brometum erecti Poldini 1980.

\begin{tabular}{lcccccccccccccccc} 
Relevé no. & 1 & 2 & 3 & 4 & 5 & 6 & 7 & 8 & 9 & 10 & 11 & 12 & 13 & 14 & 15 & 16 \\
\hline Relevé no. in Figure 1 & 19 & 20 & 22 & 29 & 30 & 36 & 37 & 49 & 50 & 59 & 44 & 45 & 54 & 55 & 60 & 61 \\
Altitude (m a.s.1.) & 614 & 613 & 610 & 530 & 530 & 733 & 728 & 596 & 696 & 612 & 589 & 596 & 648 & 652 & 673 & 673 \\
Slope $\left({ }^{\circ}\right)$ & 0 & 0 & 0 & 0 & 0 & 0 & 0 & 0 & 0 & 0 & 5 & 16 & 22 & 0 & 0 & 0 \\
Aspect & 0 & 0 & 0 & 0 & 0 & 0 & 0 & 0 & 0 & 0 & $\mathrm{~S}$ & $\mathrm{SE}$ & $\mathrm{NW}$ & 0 & 0 & 0 \\
Relevé area $\left(\mathrm{m}^{2}\right)$ & 100 & 100 & 100 & 100 & 100 & 100 & 100 & 100 & 100 & 100 & 100 & 100 & 100 & 100 & 100 & 100 \\
Cover $(\%)$ & 100 & 100 & 100 & 100 & 100 & 100 & 100 & 100 & 100 & 100 & 100 & 100 & 100 & 100 & 100 & 100
\end{tabular}

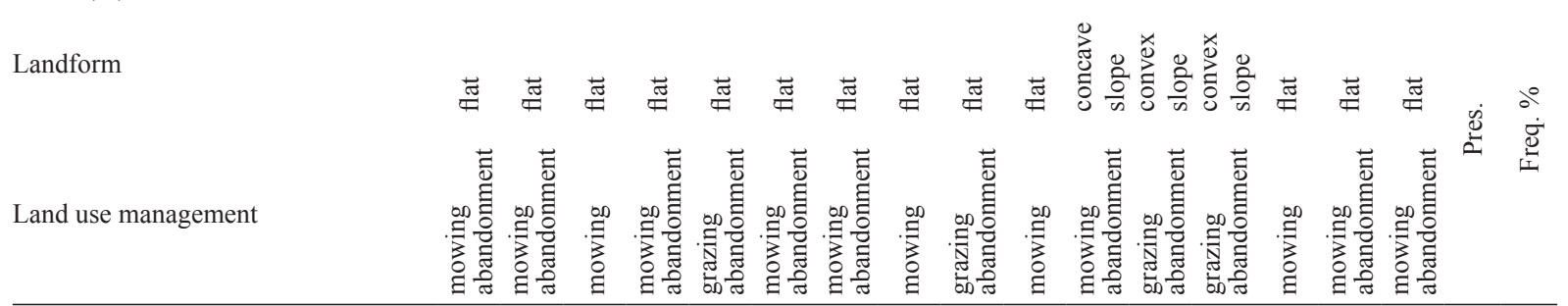

Characteristic and differential species of Anthoxantho-Brometum erecti

Knautia illyrica

Galium verum

Festuca valesiaca

Sanguisorba minor subsp. muricata

Rhinanthus minor

Trifolium campestre

$$
\begin{array}{llllllllllllllllll}
2 & 2 & + & + & + & + & + & + & + & + & + & + & 1 & + & 1 & 1 & 16 & 100 \\
1 & + & + & 1 & 2 & + & 1 & . & . & + & 1 & 1 & + & + & + & 1 & 14 & 88 \\
& & & & & + & 1 & 1 & 1 & + & 1 & 1 & 1 & 2 & 1 & 1 & 11 & 69
\end{array}
$$

Characteristic species of Arrhenatherion elatioris alliance and upper units

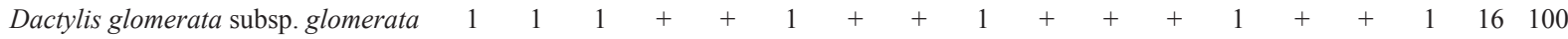

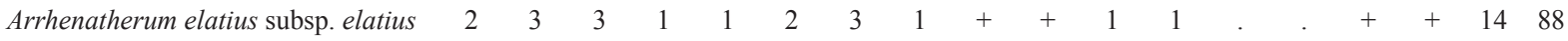

Poa pratensis

Trifolium repens subsp. repens

Anthoxanthum odoratum

Achillea millefolium

Betonica officinalis subsp. serotina

Trisetum flavescens

Trifolium pratense subsp. pratense

Prunella vulgaris

Rumex acetosa

Holcus lanatus

Plantago lanceolata

Colchicum autumnale

Gentiana pneumonanthe

Tragopogon orientalis

Plantago major

Taraxacum officinale

Ranunculus acris

Stellaria graminea

Cerastium fontanum

Thalictrum simplex subsp. galioides

Transgressive species from Scorzoneretalia villosae order and Festuco-Brometea class

Festuca rupicola

Salvia pratensis

Briza media

Medicago falcata

Brachypodium rupestre

Plantago media

$\begin{array}{cccccccccccccccccc}2 & 2 & + & 1 & + & + & 1 & 1 & 1 & + & 1 & 1 & 1 & 2 & 1 & 1 & 16 & 100 \\ 1 & 2 & + & + & + & + & + & + & + & + & + & + & 1 & 1 & 1 & 1 & 16 & 100 \\ 1 & 1 & + & + & + & + & + & + & + & + & + & + & + & 1 & + & + & 16 & 100 \\ + & + & + & + & + & 1 & 2 & 1 & + & 1 & 1 & 1 & 1 & 1 & + & 1 & 16 & 100 \\ 1 & 1 & 1 & 4 & 3 & . & . & + & 1 & + & 2 & 1 & 2 & 1 & 1 & 2 & 14 & 88 \\ + & + & 1 & . & + & . & + & + & + & + & + & + & . & + & + & + & 13 & 81\end{array}$


Relevé no.

Scorzonera villosa

Bromus erectus

Galium lucidum

Centaurea bracteata

Medicago lupulina s.1.

Polygala nicaeensis

Koeleria macrantha

Scabiosa triandra

Lotus corniculatus

Hypericum perforatum

Leucanthemum liburnicum

Carduus collinus

Lotus corniculatus subsp. hirsutus

Asperula aristata s.1.

Anthyllis vulneraria

Tragopogon pratensis

Buphthalmum salicifolium

Euphorbia verrucosa

Globularia punctata

Hippocrepis comosa

Genista sylvestris

Centaurea triumfettii subsp. adscendens

Stachys subcrenata

Carex humilis

Thymus longicaulis

Gentiana cruciata

Koeleria splendens

Trifolium montanum

Euphorbia cyparissias

Thymus pulegioides

Dianthus balbisii subsp. liburnicus

Daucus carota

Ononis spinosa subsp. antiquorum

Rhinanthus freynii

Centaurea weldeniana

Danthonia alpina

Eryngium amethystinum

Teucrium chamaedrys

Orchis militaris

Vicia cracca

Arabis hirsuto

Galium corrudifolium

Sesleria juncifolia

Bromus condensatus

Tragopogon dubius

Allium carinatum

Prunella laciniata

Hypochaeris maculata

Carex flacca s.1.

Inula hirta

Leontodon crispus

Scorzonera austriaca

Teucrium montanum

Genista sericea

\begin{tabular}{lllllllllllllllll}
1 & 2 & 3 & 4 & 5 & 6 & 7 & 8 & 9 & 10 & 11 & 12 & 13 & 14 & 15 & 16 & Pres. Fr. $\%$ \\
\hline
\end{tabular}

$++.++++1+1+1+1381$

$++2+3+2+2+2 \quad 1 \quad 2 \quad 2 \quad 2 \quad 1381$

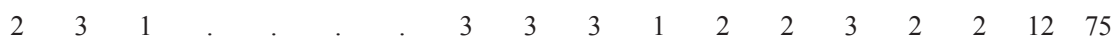

$+\quad+1 .+\quad+\quad+1 .+1 .+1275$

$\begin{array}{lllllllllllll}2 & 3 & 1 & 1 & 3 & + & + & + & + & 11 & 69\end{array}$

$+\quad+\quad+1169$

$+\quad+\quad+1169$

$1+\quad+\quad 1169$

$+\quad+\quad 11063$

. . 956

. $+\quad+956$

$+\quad+\quad 850$

$++++850$

$++++744$

$+\quad+\quad+744$

$++++744$

. . 744

. +11744

$+\quad . \quad 638$

$++++638$

$++++638$

$++++531$

$+\quad . \quad 531$

$+\quad+\quad+531$

$1+++531$

$++. \quad+\quad 531$

. . 531

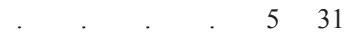

$+++\quad 531$

$+\quad$. 531

. $. \quad+531$

$+\quad+\quad+\quad 531$

. . . 425

. $1+425$

$\begin{array}{ll}1 & 1 \\ + & 425\end{array}$

$++++425$

$+\quad+425$

$+\quad+425$

. 425

. +425

. 425

$+\quad+425$

. 425

. 319

. 319

$+\quad+\quad 319$

$+\quad+319$

$+\quad+213$

. 213

. 213

$+\quad+\quad 213$

$\begin{array}{rrrr}. & \cdot & 2 & 13 \\ + & . & 2 & 13\end{array}$

$+. \quad 213$

$\begin{array}{ll}2 & 13 \\ 2 & 13\end{array}$ 
Relevé no.

\begin{tabular}{lllllllllllllllll}
1 & 2 & 3 & 4 & 5 & 6 & 7 & 8 & 9 & 10 & 11 & 12 & 13 & 14 & 15 & 16 & Pres. Fr. $\%$ \\
\hline
\end{tabular}

Centaurea rupestris

Dianthus sylvestris subsp. tergestinus

Orchis morio

Ferulago galbanifera

Asphodelus albus

Thalictrum minus

Prunella grandiflora

Ingressive species from Trifolio-Geranietea sanguinei class

Lathyrus latifolius

Knautia drymeia

Campanula rapunculus

Scorzonera hispanica

Orobanche lutea

Trifolium alpestre

Agrimonia eupatoria

Coronilla coronata

Veronica jacquinii

Seseli libanotis

Trifolium rubens

Valeriana wallrothii

Veronica chamaedrys

Serratula lycopifolia

Anthericum ramosum s.1.

Polygonatum odoratum

Chamaecytisus hirsutus

Viola hirta

Companions

Elymus repens

Sedum acre

Dorycnium pentaphyllum

Pastinaca sativa

Picris echioides

Vicia villosa

Briza minor

Crataegus monogyna

Prunus mahaleb

Rubus caesius

Plantago argentea

Ajuga reptans

Erigeron annuus

Petrorhagia saxifraga

Pyrus pyraster

Calamagrostis varia

Rhinanthus glacialis

Medicago sativa

Helleborus multifidus subsp. istriacus

Senecio erucifolius

Cirsium arvense

Convolvulus arvensis

Silene latifolia subsp. alba

Rumex crispus

Galium mollugo

Juniperus communis

Acer campestre

Fraxinus excelsior

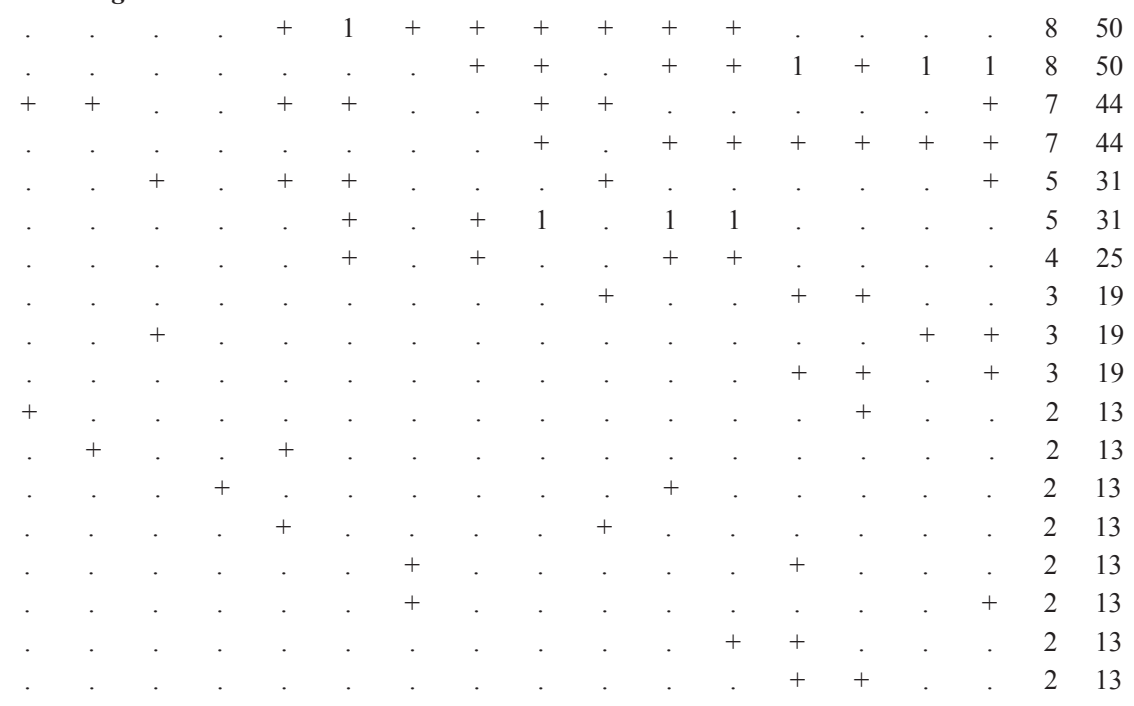




\begin{tabular}{|c|c|c|c|c|c|c|c|c|c|c|c|c|c|c|c|c|c|c|}
\hline Relevé no. & 1 & 2 & 3 & 4 & 5 & 6 & 7 & 8 & 9 & 10 & 11 & 12 & 13 & 14 & 15 & 16 & Pres. & Fr. $\%$ \\
\hline Fraxinus ornus & . & . & + & . & . & . & . & . & . & . & + & . & . & . & . & . & 2 & 13 \\
\hline Cytisus nigricans & . & . & . & . & . & . & . & . & . & . & + & . & . & 1 & . & . & 2 & 13 \\
\hline Allium roseum & . & . & . & . & . & . & . & . & . & + & . & . & + & . & . & . & 2 & 13 \\
\hline Genista sagittalis s.l. & . & . & . & . & . & . & . & . & . & . & . & . & + & + & . & . & 2 & 13 \\
\hline Luzula luzuloides & 1 & + & . & . & . & . & . & . & . & . & . & . & . & . & . & . & 2 & 13 \\
\hline Viola odorata & . & . & . & . & . & + & . & . & . & . & . & + & . & . & . & . & 2 & 13 \\
\hline Carex sp. & . & . & . & + & + & . & . & . & . & . & . & . & . & . & . & . & 2 & 13 \\
\hline Hypericum tetrapterum & . & . & . & . & . & . & . & . & . & . & . & . & + & + & . & . & 2 & 13 \\
\hline Trifolium alpinum & . & . & + & . & . & . & . & . & . & + & . & . & . & . & . & . & 2 & 13 \\
\hline Accidental & 3 & 2 & 8 & 3 & 2 & 3 & 2 & 1 & 1 & 2 & 0 & 3 & 2 & 2 & 1 & 1 & & \\
\hline
\end{tabular}

Table 4: Synoptic table of Cićarija grassland vegetation, compared with phytosociological tables from Istria and surrounding territories, based on data collected in the past decades [column 1: cluster I, table 2 - DanthonioScorzoneretum villosae Horvat \& Horvatić in Horvatić 1958 (present study); column 2: Danthonio-Scorzoneretum villosae Horvat \& Horvatić in Horvatić 1958 (rel. 44-48, Table 1 in Kaligarič \& Poldini 1997); column 3: subcluster $\mathrm{IIa}^{1}$, Table 3 - Carici humilis-Centaureetum rupestris Horvat 1931 (present study); column 4: subcluster IIa ${ }^{2}$, Table 3 - Carici humilis-Centaureetum rupestris Horvat 1931 Brachypodium rupestre variant (present study); column 5: Carici humilis-Centaureetum rupestris Horvat 1931 (rel. 41-50, Table 2 in Kaligarič \& Poldini 1997); column 6: subcluster IIb, table 4 - Anthoxantho-Brometum erecti Poldini 1980 (present study); column 7: Anthoxantho-Brometum erecti Poldini 1980 [sub Arrhenatheretum elatioris sensu Poldini non Br.-Bl. 1925 brometosum erecti (rel. 13-33, Table 56 in Poldini 1989)].

Tabela 4: Sinoptična tabela vegetacije travnikov v Ćićariji in primerjava s fitocenološkim gradivom iz Istre in sosednjih območij [stolpec 1: klaster I, tabela 2 - Danthonio-Scorzoneretum villosae Horvat \& Horvatić in Horvatić 1958 (ta članek); stolpec 2: Danthonio-Scorzoneretum villosae Horvat \& Horvatić in Horvatić 1958 (popisi 44-48, tabela 1 v Kaligarič \& Poldini 1997); stolpec 3: subklaster IIa ${ }^{1}$, tabela 3 - Carici humilis-Centaureetum rupestris Horvat 1931 (ta članek); stolpec 4: subklaster IIa ${ }^{2}$, tabela 3 - Carici humilis-Centaureetum rupestris Horvat 1931 Brachypodium rupestre varianta (ta članek); stolpec 5: Carici humilis-Centaureetum rupestris Horvat 1931 (popisi 41-50, tabela 2 v Kaligarič \& Poldini 1997); stolpec 6: subklaster IIb, tabela 4 - Anthoxantho-Brometum erecti Poldini 1980 (ta članek); stolpec 7: Anthoxantho-Brometum erecti Poldini 1980 [sub Arrhenatheretum elatioris sensu Poldini non Br.-Bl. 1925 brometosum erecti (popisi 13-33, tabela 56 v Poldini 1989)].

\begin{tabular}{|c|c|c|c|c|c|c|}
\hline Column no. & 1 & 2 & 3 & 4 & 5 & 6 \\
\hline No. of relevés & 17 & 5 & 14 & 26 & 10 & 16 \\
\hline
\end{tabular}

Characteristic species of Scorzonerion villosae alliance

Knautia illyrica

Leucanthemum liburnicum

Daucus carota

Rhinanthus freynii

Medicago falcata

Ferulago galbanifera

Hypochaeris maculata

Dianthus sanguineus

Ranunculus bulbosus

Dorycnium herbaceum

Prunella laciniata

Melampyrum barbatum subsp. carstiense

\begin{tabular}{|c|c|c|c|c|c|c|}
\hline IV & III & II & V & I & $\mathrm{V}$ & . \\
\hline III & $\mathrm{V}$ & I & II & I & III & . \\
\hline II & . & I & I & . & II & IV \\
\hline I & II & . & I & . & II & I \\
\hline III & . & I & IV & . & $\mathrm{V}$ & II \\
\hline . & $\mathrm{V}$ & II & I & . & I & I \\
\hline I & II & . & I & . & I & . \\
\hline . & II & I & I & . & I & . \\
\hline I & I & . & . & . & . & IV \\
\hline I & . & I & . & . & . & I \\
\hline II & . & . & I & . & I & . \\
\hline II & . & . & I & . & . & . \\
\hline
\end{tabular}

Characteristic and differential species of Saturejienion subspicatae suballiance and Saturejion subspicatae alliance

Centaurea rupestris

Carex humilis
I III

I III

$\begin{array}{ll}\text { V } & \text { V } \\ \text { V } & \text { III }\end{array}$

III

21




No. of relevés
Bromus condensatus
Stachys subcrenata
Dorycnium germanicum
Euphorbia verrucosa
Teucrium montanum
Scorzonera austriaca
Muscari botryoides
Gentiana tergestina
Centaurea cristata subsp. tommasinii
Stipa pennata subsp. eriocaulis
Satureja montana subsp. subspicata
Dianthus sylvestris subsp. tergestinus
Seseli elatum subsp. gouanii
Globularia cordifolia
Crepis chondrilloides
Euphrasia illyrica

Characteristic species of Scorzoneretalia villosae order

Scorzonera villosa

Festuca rupicola

Polygala nicaeensis

Salvia pratensis

Lotus corniculatus subsp. hirsutus

Globularia punctata

Thymus longicaulis

Galium lucidum

Centaurea triumfettii subsp. adscendens

Leontodon crispus

Genista sylvestris

Lathyrus latifolius

Centaurea weldeniana

Pseudolysimachion spicatum subsp. barrelieri

Euphorbia nicaeensis

Asperula cynanchica

Koeleria splendens

Inula hirta

Plantago holosteum

Chrysopogon gryllus

Danthonia alpina

Potentilla tommasiniana

Cirsium acaule

Centaurea bracteata

Inula ensifolia

Allium senescens subsp. montanum

Buphthalmum salicifolium

Betonica officinalis subsp. serotina

Genista sericea

Narcissus radiiflorus

Potentilla alba

Serratula lycopifolia

Linum narbonense

Gentiana cruciata

\begin{tabular}{|c|c|c|c|c|c|c|}
\hline 17 & 5 & 14 & 26 & 10 & 16 & 21 \\
\hline III & . & IV & III & . & I & . \\
\hline I & . & IV & IV & . & II & . \\
\hline . & IV & IV & I & IV & . & . \\
\hline . & IV & I & IV & . & II & . \\
\hline . & . & IV & IV & V & I & . \\
\hline . & . & III & III & II & I & . \\
\hline I & . & II & . & I & . & . \\
\hline I & . & . & I & I & . & . \\
\hline I & . & . & I & I & . & . \\
\hline . & . & IV & II & II & . & . \\
\hline . & . & IV & I & I & . & . \\
\hline . & . & II & II & . & I & . \\
\hline . & . & I & I & . & . & . \\
\hline . & . & III & . & . & . & . \\
\hline . & . & I & . & . & . & . \\
\hline . & . & . & . & I & . & . \\
\hline
\end{tabular}

\begin{tabular}{|c|c|c|c|c|c|}
\hline III & $\mathrm{V}$ & IV & $\mathrm{V}$ & III & $\mathrm{V}$ \\
\hline III & III & II & IV & IV & $\mathrm{V}$ \\
\hline III & III & III & IV & II & IV \\
\hline $\mathrm{V}$ & $\mathrm{V}$ & IV & $\mathrm{V}$ & II & $\mathrm{V}$ \\
\hline III & $\mathrm{V}$ & I & $\mathrm{V}$ & II & III \\
\hline II & $\mathrm{V}$ & V & III & IV & II \\
\hline II & III & I & III & IV & II \\
\hline I & IV & I & III & II & IV \\
\hline I & I & I & III & I & II \\
\hline I & II & II & I & II & I \\
\hline I & II & III & IV & III & II \\
\hline III & II & I & I & . & III \\
\hline . & II & I & I & II & II \\
\hline I & I & I & I & . & I \\
\hline I & II & IV & II & IV & . \\
\hline I & I & III & I & III & . \\
\hline III & . & III & III & IV & II \\
\hline I & . & IV & II & I & I \\
\hline . & IV & III & III & III & I \\
\hline III & IV & I & . & I & . \\
\hline I & II & . & II & . & II \\
\hline I & I & . & I & III & . \\
\hline II & . & I & I & II & . \\
\hline I & . & III & III & . & IV \\
\hline I & . & II & II & . & I \\
\hline I & . & II & I & I & . \\
\hline I & . & I & IV & . & III \\
\hline I & I & III & III & IV & II \\
\hline . & . & I & II & II & I \\
\hline I & . & III & I & . & . \\
\hline I & . & I & I & . & . \\
\hline I & . & . & I & . & I \\
\hline . & . & II & I & . & I \\
\hline . & . & I & II & . & II \\
\hline
\end{tabular}


No. of relevés

\begin{tabular}{ccccccc}
17 & 5 & 14 & 26 & 10 & 16 & 21 \\
\hline I &. &. & I &. & $\cdot$ & $\cdot$ \\
I &. & I &. &. & $\cdot$ & $\cdot$ \\
. &. & I & I &. &. &. \\
. & II &. &. &. &. & $\cdot$ \\
. &. &. &. & I &. &.
\end{tabular}

\section{Characteristic species of Festuco-Brometea class}

Plantago media

Bromus erectus

Filipendula vulgaris

Hippocrepis comosa

Teucrium chamaedrys

Briza media

Sanguisorba minor

Eryngium amethystinum

Euphorbia cyparissias

Trifolium montanum

Carex flacca s.1.

Anthyllis vulneraria

Lotus corniculatus

Galium verum

Festuca valesiaca

Brachypodium rupestre

Medicago lupulina

Trifolium campestre

Scabiosa triandra

Tragopogon pratensis

Thymus pulegioides

Galium corrudifolium

Brachypodium pinnatum

Orchis militaris

Thalictrum minus

Allium sphaerocephalon

Linum tenuifolium

Hypericum perforatum

Plantago argentea

Carduus collinus

Linum catharticum

Vicia cracca

Potentilla heptaphylla

Satureja montana subsp. montana

Asperula aristata s.1.

Knautia purpurea

Orchis morio

Satureja montana subsp. variegata

Achillea collina

Koeleria pyramidata

Trinia glauca

Sanguisorba minor subsp. muricata

Jurinea mollis

Sesleria juncifolia

Stachys recta

\begin{tabular}{|c|c|c|c|c|c|c|}
\hline IV & $\mathrm{V}$ & I & III & III & $\mathrm{V}$ & $\mathrm{V}$ \\
\hline II & $\mathrm{V}$ & I & III & $\mathrm{V}$ & IV & IV \\
\hline III & $\mathrm{V}$ & $\mathrm{V}$ & $\mathrm{V}$ & I & $\mathrm{V}$ & . \\
\hline III & III & II & III & I & II & . \\
\hline II & I & IV & IV & IV & II & . \\
\hline III & II & . & IV & I & V & III \\
\hline II & III & I & II & . & II & $\mathrm{V}$ \\
\hline I & III & IV & IV & $\mathrm{V}$ & II & . \\
\hline I & I & IV & IV & IV & II & . \\
\hline I & $\mathrm{V}$ & II & I & . & II & . \\
\hline I & . & I & I & I & I & . \\
\hline III & . & IV & $\mathrm{V}$ & . & III & II \\
\hline II & . & III & II & . & III & $\mathrm{V}$ \\
\hline I & . & . & III & I & $\mathrm{V}$ & III \\
\hline I & I & I & IV & . & IV & IV \\
\hline I & III & I & . & I & . & . \\
\hline III & . & . & I & . & IV & $\mathrm{V}$ \\
\hline III & . & . & I & . & II & III \\
\hline IV & III & I & II & III & IV & II \\
\hline II & . & III & I & . & III & . \\
\hline II & . & I & I & . & II & III \\
\hline I & . & IV & IV & . & II & . \\
\hline I & . & I & $\mathrm{V}$ & . & $\mathrm{V}$ & . \\
\hline I & . & I & II & . & II & . \\
\hline . & . & III & V & II & I & . \\
\hline . & . & I & I & III & I & . \\
\hline . & . & I & I & III & I & . \\
\hline . & . & I & I & I & III & . \\
\hline . & . & I & I & I & II & . \\
\hline . & . & II & IV & . & III & I \\
\hline I & II & I & . & . & . & . \\
\hline II & . & . & . & . & II & I \\
\hline I & . & II & II & . & . & . \\
\hline I & . & II & II & . & . & . \\
\hline I & . & . & III & . & III & . \\
\hline I & . & . & I & . & I & . \\
\hline I & . & . & I & . & I & . \\
\hline . & I & II & . & IV & . & $\cdot$ \\
\hline . & I & . & . & I & . & IV \\
\hline . & I & II & I & . & . & . \\
\hline . & II & II & . & II & . & . \\
\hline . & . & I & II & IV & . & . \\
\hline . & . & III & I & II & . & . \\
\hline . & . & III & III & . & I & . \\
\hline . & . & . & I & I & I & . \\
\hline
\end{tabular}


No. of relevés

Allium carinatum

Leucanthemum vulgare

Ononis spinosa subsp. antiquorum

Anthyllis vulneraria subsp. poliphylla

Helianthemum ovatum

Carex caryophyllea

Pulsatilla montana

Hieracium pilosella

Leontodon hispidus

Anthyllis montana subsp. jacquinii

Melica ciliata

Senecio scopolii

Cuscuta epithymum

Phyteuma orbiculare

Salvia sclarea

Senecio doronicum

Arabis hirsuta

Dianthus monspessulanus

Koeleria macrantha

Dianthus balbisii subsp. liburnicus

Hieracium bauhinii

Asphodelus albus

Prunella grandiflora

Silene vulgaris

Tragopogon dubius

Onobrychis viciifolia

Polygala vulgaris

Carex montana

Onobrychis arenaria

Orchis ustulata

Festuca rubra

Globularia meridionalis

Asperula purpurea

Medicago prostrata

Agropyron intermedium

Thesium divaricatum

Hieracium piloselloides

Campanula glomerata

Hyssopus officinalis subsp. aristatus

Avenula pubescens

Cerastium tenoreanum

Pimpinella saxifraga

\begin{tabular}{|c|c|c|c|c|c|c|}
\hline 17 & 5 & 14 & 26 & 10 & 16 & 21 \\
\hline . & . & . & I & I & I & . \\
\hline . & . & . & I & . & I & $\mathrm{V}$ \\
\hline III & . & . & . & . & II & . \\
\hline . & IV & . & . & III & . & . \\
\hline . & IV & . & . & II & . & . \\
\hline . & III & . & . & I & . & . \\
\hline . & II & . & . & II & . & . \\
\hline . & II & . & . & I & . & . \\
\hline . & I & . & . & . & . & $\mathrm{V}$ \\
\hline . & . & II & III & . & . & . \\
\hline . & . & IV & I & . & . & . \\
\hline . & . & I & III & . & . & . \\
\hline . & . & I & I & . & . & . \\
\hline . & . & I & I & . & . & . \\
\hline . & . & I & I & . & . & . \\
\hline . & . & I & I & . & . & . \\
\hline . & . & II & . & . & II & . \\
\hline . & . & I & . & . & I & . \\
\hline . & . & . & III & . & IV & . \\
\hline . & . & . & I & . & II & . \\
\hline . & . & . & I & . & I & . \\
\hline . & . & . & I & . & I & . \\
\hline . & . & . & I & . & I & . \\
\hline . & . & . & I & . & I & . \\
\hline$\cdot$ & . & . & I & . & I & . \\
\hline II & . & . & . & . & . & . \\
\hline I & . & . & . & . & . & . \\
\hline . & I & . & . & . & . & . \\
\hline . & I & . & . & . & . & . \\
\hline . & I & . & . & . & . & . \\
\hline . & . & II & . & . & . & . \\
\hline . & . & . & I & $\cdot$ & . & . \\
\hline . & . & . & . & IV & . & . \\
\hline . & . & . & . & III & . & . \\
\hline . & . & . & . & II & . & . \\
\hline$\cdot$ & $\cdot$ & . & $\cdot$ & II & . & . \\
\hline . & . & . & . & II & . & . \\
\hline . & . & . & . & I & . & . \\
\hline . & . & . & . & I & . & . \\
\hline . & . & . & . & $\cdot$ & . & III \\
\hline$\cdot$ & . & $\cdot$ & $\cdot$ & . & . & II \\
\hline . & . & . & . & . & . & II \\
\hline
\end{tabular}

Characteristic species of Arrhenatherion alliance, Arrhenatheretalia order and Molinio-Arrhenatheretea class

Plantago lanceolata

Dactylis glomerata

Anthoxanthum odoratum

Trifolium pratense subsp. pratense

Poa pratensis

Arrhenatherum elatius subsp. elatius

Trisetum flavescens

Rhinanthus minor

$\begin{array}{ccccccc}\text { V } & \text { I } & \text { II } & \text { II } & . & \text { II } & \text { V } \\ \text { II } & \text { II } & \text { I } & \text { III } & . & \text { V } & \text { IV } \\ \text { I } & \text { III } & \text { I } & \text { I } & . & \text { III } & \text { V } \\ \text { IV } & \text { III } & . & . & . & \text { II } & \text { V } \\ \text { III } & . & . & \text { II } & \cdot & \text { V } & \text { V } \\ \text { I } & . & . & \text { I } & \cdot & \text { V } & \text { V } \\ \text { II } & . & . & \text { I } & . & \text { II } & \text { III } \\ \text {. } & \text { I } & . & \text { I } & . & \text { II } & \text { II }\end{array}$


No. of relevés

17

Achillea millefolium

Prunella vulgaris

Trifolium repens

Colchicum autumnale

Tragopogon orientalis

Holcus lanatus

Cerastium fontanum

Ranunculus acris

Stellaria graminea

Plantago major

Lathyrus pratensis

Tragopogon porrifolius

Plantago altissima

Senecio jacobaea

Gentiana pneumonanthe

Thalictrum simplex subsp. galioides

Rumex acetosa

Taraxacum officinale

Centaurea jacea

Crepis biennis

Genista tinctoria

Lolium perenne

Galium album

Festuca pratensis

Bellis perennis

\section{Companions}

Trifolium rubens

Luzula multiflora

Trifolium alpestre

Picris hieracioides

Chamaecytisus hirsutus

Sedum acre

Scorzonera hispanica

Seseli libanotis

Orobanche lutea

Dorycnium pentaphyllum

Knautia drymeia

Helleborus multifidus subsp. istriacus

Pinus nigra

Elymus repens

Juniperus communis

Allium species

Petrorhagia saxifraga

Peucedanum oreoselinum

Pastinaca sativa

Rhinanthus glacialis

Anthericum ramosum

Viola hirta

Inula salicina

Helianthemum salicifolium

Geranium sanguineum

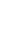

I

I

\begin{tabular}{lllll}
14 & 26 & 10 & 16 & 21 \\
\hline
\end{tabular}

. . II I III

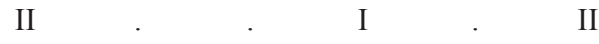

I . . . I $\quad$ I $\quad$ III




\begin{tabular}{|c|c|c|c|c|c|c|c|}
\hline No. of relevés & 17 & 5 & 14 & 26 & 10 & 16 & 21 \\
\hline Dictamnus albus & I & . & $\mathrm{I}$ & $\mathrm{I}$ & . & . & . \\
\hline Rosa canina & $\mathrm{I}$ & . & III & III & . & . & . \\
\hline Campanula rapunculus & II & . & . & I & . & III & . \\
\hline Peucedanum cervaria & $\mathrm{I}$ & . & . & II & . & I & . \\
\hline Briza minor & I & . & . & I & . & II & . \\
\hline Lilium bulbiferum & I & . & . & I & . & $\mathrm{I}$ & . \\
\hline Silene latifolia subsp. alba & I & . & . & I & . & $\mathrm{I}$ & . \\
\hline Senecio erucifolius & I & . & . & I & . & I & . \\
\hline Convolvulus arvensis & I & . & . & I & . & $\mathrm{I}$ & . \\
\hline Cirsium arvense & I & . & . & I & . & $\mathrm{I}$ & . \\
\hline Clematis vitalba & I & . & . & I & . & $\mathrm{I}$ & . \\
\hline Rubus caesius & $\mathrm{I}$ & . & . & I & . & II & . \\
\hline Medicago sativa & III & . & . & . & . & $\mathrm{I}$ & I \\
\hline Tragopogon tommasinii & . & II & . & . & I & . & II \\
\hline Serratula radiata & . & . & I & I & I & . & . \\
\hline Prunus mahaleb & . & . & II & III & . & II & . \\
\hline Laserpitium siler & . & . & II & III & . & $\mathrm{I}$ & . \\
\hline Cornus mas & . & . & $\mathrm{I}$ & II & . & $\mathrm{I}$ & . \\
\hline Crataegus monogyna & . & . & I & I & . & II & . \\
\hline Polygonatum odoratum & . & . & I & I & . & $\mathrm{I}$ & . \\
\hline Fraxinus ornus & . & . & I & I & . & I & . \\
\hline Campanula pyramidalis & . & . & I & I & . & I & . \\
\hline Ajuga reptans & . & . & . & I & . & I & II \\
\hline Dorycnium hirsutum & II & . & $\mathrm{I}$ & . & . & . & . \\
\hline Carduus nutans & I & . & I & . & . & . & . \\
\hline Cerastium arvense subsp. strictum & I & . & I & . & . & . & . \\
\hline Dactylis glomerata subsp. hispanica & III & . & . & II & . & . & . \\
\hline Scolymus hispanicus & I & . & . & I & . & . & . \\
\hline Acinos arvensis & $\mathrm{I}$ & . & . & I & . & . & . \\
\hline Poa bulbosa & I & . & . & I & . & . & . \\
\hline Quercus cerris & I & . & . & I & . & . & . \\
\hline Carex species & II & . & . & . & . & I & . \\
\hline Cichorium intybus & I & . & . & . & . & I & . \\
\hline Galium mollugo & $\mathrm{I}$ & . & . & . & . & I & . \\
\hline Erigeron annuus & I & . & . & . & . & $\mathrm{I}$ & . \\
\hline Rumex crispus & $\mathrm{I}$ & . & . & . & . & I & . \\
\hline Carduus pycnocephalus & I & . & . & . & . & I & . \\
\hline Crepis sancta & $\mathrm{I}$ & . & . & . & . & I & . \\
\hline Vicia angustifolia & $\mathrm{I}$ & . & . & . & . & . & III \\
\hline Bothriochloa ischaemon & . & I & . & . & II & . & . \\
\hline Verbascum blattaria & . & . & II & I & . & . & . \\
\hline Bunium alpinum subsp. montanum & . & . & I & II & . & . & . \\
\hline Vincetoxicum hirundinaria & . & . & $\mathrm{I}$ & II & . & . & . \\
\hline Euphorbia characias subsp. wulfenii & . & . & $\mathrm{I}$ & $\mathrm{I}$ & . & . & . \\
\hline Inula spiraeifolia & . & . & I & I & . & . & . \\
\hline Viola odorata & . & . & I & . & . & $\mathrm{I}$ & . \\
\hline Rhamnus fallax & . & . & . & II & . & I & . \\
\hline Trifolium alpinum & . & . & . & II & . & I & . \\
\hline Agrimonia eupatoria & . & . & . & $\mathrm{I}$ & . & II & . \\
\hline Vicia villosa & . & . & . & I & . & II & . \\
\hline Allium roseum & . & . & . & I & . & I & . \\
\hline
\end{tabular}


No. of relevés 17 5

Veronica jacquinii

Genista sagittalis

Gentiana lutea subsp. symphyandra

Cytisus nigricans

Coronilla coronata

Aristolochia clematitis

Echium vulgare

Rhamnus saxatilis

Acer campestre

Valeriana wallrothii

Calamintha menthifolia

Fragaria vesca

Fraxinus excelsior

Prunus spinosa

Paeonia mascula

Potentilla reptans

Veronica chamaedrys

Euphorbia palustris

Danthonia decumbens

Filago vulgaris

Aira elegantissima

Stellaria holostea

Calamagrostis arundinacea

Hypericum hirsutum

Vicia sativa

Chamaespartium sagittale

Festuca tenuifolia

Potentilla recta

Calamintha nepeta

Verbascum chaixii

Silene italica

Lotus angustissimus

Apera spica-venti

Salix caprea

Sorbus aucuparia

Thlaspi perfoliatum

Verbascum pulverulentum

Juniperus oxycedrus subsp. macrocarpa

Frangula rupestris

Bupleurum veronense

Artemisia alba

Fumana procumbens

Viola rupestris

Picris echioides

Luzula luzuloides

Calamagrostis varia

Hypericum tetrapterum

Pyrus communis

Crepis taraxacifolia

Veronica arvensis

Myosotis arvensis 


\begin{tabular}{|c|c|c|c|c|c|c|c|}
\hline No. of relevés & 17 & 5 & 14 & 26 & 10 & 16 & 21 \\
\hline Coronilla varia & . & . & . & . & . & . & II \\
\hline Sedum sexangulare & . & . & . & . & . & . & II \\
\hline Cerastium glutinosum & . & . & . & . & . & . & II \\
\hline Bromus hordeaceus & . & . & . & . & . & . & I \\
\hline Centaurea vochinensis & . & . & . & . & . & . & $\mathrm{I}$ \\
\hline
\end{tabular}

Table 5: Social behaviour type composition (in \%) of Cićarija grassland syntaxa, compared with the one of the same syntaxa, surveyed in the past decades in Istria and surrounding territories. Column numbers are the same as reported in Table 4.

Tabela 5: Sestava zgradbe travniških združb glede na sinsociološko pripadnost vrst (v \%) travniških sintaksonov Ćićarije. Primerjava popisnega gradiva s popisi narejenimi v preteklih destletjih in iz sosednjih območij. Številke stolpcev so enake kot v Tabeli 4.

\begin{tabular}{|c|c|c|c|c|c|c|c|}
\hline Social behaviour type & 1 & 2 & 3 & 4 & 5 & 6 & 7 \\
\hline Pasture & 57.1 & 82.7 & 71.2 & 57.1 & 90.7 & 50.0 & 50.0 \\
\hline Meadow & 11.2 & 9.3 & 3.4 & 8.2 & 1.2 & 10.6 & 25.0 \\
\hline Successional and ruderal & 29.8 & 8.0 & 23.3 & 33.3 & 8.1 & 36.2 & 25.0 \\
\hline Other & 1.9 & 0.0 & 2.1 & 1.4 & 0.0 & 3.2 & 0.0 \\
\hline
\end{tabular}

Table 6: Management type, landform, and dynamic state related to use/non-use, of the identified grassland syntaxa. Possible trends in case of protracted abandonment are also shown.

Tabela 6: Način gospodarjenja, krajinska oblika in dinamično stanje glede na status uporabe/neuporabe v ugotovljenih travniških sintaksonih. Nakazani so možni trendi v primeru nadaljnega opuščanja.

\begin{tabular}{|l|l|l|l|}
\hline Management type & \multicolumn{1}{|c|}{ Pasture } & \multicolumn{2}{c|}{ Meadow } \\
\hline Landform & $\begin{array}{l}\text { Flat or slightly convex relief } \\
\text { tops, slightly or moderately steep } \\
\text { slopes, with shallow soils and } \\
\text { outcropping rock }\end{array}$ & $\begin{array}{l}\text { Flat or slightly concave surfaces, } \\
\text { at the transition between slopes } \\
\text { and flat lands, with quite deep } \\
\text { soils }\end{array}$ & $\begin{array}{l}\text { Flat lands, bottom of depressions } \\
\text { between relief tops, with deep } \\
\text { soils }\end{array}$ \\
\hline Use & $\begin{array}{l}\text { Carici humilis-Centaureetum } \\
\text { rupestris }\end{array}$ & $\begin{array}{l}\text { Danthonio-Scorzoneretum } \\
\text { villosae }\end{array}$ & $\begin{array}{l}\text { Arrhenatheretum elatioris } \\
\text { "typicum" }\end{array}$ \\
\hline Abandonment & Brachypodium rupestre variant & Brachypodium rupestre variant? & Anthoxantho-Brometum erecti \\
\hline $\begin{array}{l}\text { Protracted } \\
\text { abandonment }\end{array}$ & $\begin{array}{l}\text { Brachypodium rupestre } \\
\text { community? }\end{array}$ & $\begin{array}{l}\text { Brachypodium rupestre } \\
\text { community? }\end{array}$ & $\begin{array}{l}\text { Nitrophilous tall herbs } \\
\text { community? }\end{array}$ \\
\hline
\end{tabular}

